\title{
Natural organobromine in marine sediments: New evidence of biogeochemical $\mathrm{Br}$ cycling
}

\author{
Alessandra C. Leri, ${ }^{1,2}$ J. Alexandra Hakala, ${ }^{3}$ Matthew A. Marcus, ${ }^{4}$ Antonio Lanzirotti, ${ }^{5}$ \\ Christopher M. Reddy, ${ }^{6}$ and Satish C. B. Myneni ${ }^{1,3,7}$ \\ Received 22 January 2010; revised 6 July 2010; accepted 4 August 2010; published 24 November 2010.
}

[1] Organobromine $\left(\mathrm{Br}_{\text {org }}\right)$ compounds, commonly recognized as persistent, toxic anthropogenic pollutants, are also produced naturally in terrestrial and marine systems. Several enzymatic and abiotic bromination mechanisms have been identified, as well as an array of natural $\mathrm{Br}_{\text {org }}$ molecules associated with various marine organisms. The fate of the carbon-bromine functionality in the marine environment, however, remains largely unexplored. Oceanographic studies have noted an association between bromine $(\mathrm{Br})$ and organic carbon $\left(\mathrm{C}_{\text {org }}\right)$ in marine sediments. Even so, there has been no direct chemical evidence that $\mathrm{Br}$ in the sediments exists in a stable form apart from inorganic bromide $\left(\mathrm{Br}_{\text {inorg }}\right)$, which is widely presumed conservative in marine systems. To investigate the scope of natural $\mathrm{Br}_{\text {org }}$ production and its fate in the environment, we probed $\mathrm{Br}$ distribution and speciation in estuarine and marine sediments using in situ X-ray spectroscopy and spectromicroscopy. We show that $\mathrm{Br}_{\text {org }}$ is ubiquitous throughout diverse sedimentary environments, occurring in correlation with $\mathrm{C}_{\text {org }}$ and metals such as $\mathrm{Fe}, \mathrm{Ca}$, and $\mathrm{Zn}$. Analysis of sinking particulate carbon from the seawater column links the $\mathrm{Br}_{\text {org }}$ observed in sediments to biologically produced $\mathrm{Br}_{\text {org }}$ compounds that persist through humification of natural organic matter (NOM). Br speciation varies with sediment depth, revealing biogeochemical cycling of $\mathrm{Br}$ between organic and inorganic forms as part of the burial and degradation of NOM. These findings illuminate the chemistry behind the association of $\mathrm{Br}$ with $\mathrm{C}_{\text {org }}$ in marine sediments and cast doubt on the paradigmatic classification of $\mathrm{Br}$ as a conservative element in seawater systems.

Citation: Leri, A. C., J. A. Hakala, M. A. Marcus, A. Lanzirotti, C. M. Reddy, and S. C. B. Myneni (2010), Natural organobromine in marine sediments: New evidence of biogeochemical Br cycling, Global Biogeochem. Cycles, 24, GB4017, doi:10.1029/2010GB003794.

\section{Introduction}

[2] Organobromine $\left(\mathrm{Br}_{\text {org }}\right)$ chemicals are synthesized industrially for various uses and have gained notoriety as persistent environmental toxins. Polybrominated diphenyl ether (PBDE) flame retardants, for instance, are widely used in

\footnotetext{
${ }^{1}$ Department of Chemistry, Princeton University, Princeton, New Jersey, USA.

${ }^{2}$ Now at Department of Natural Sciences and Mathematics, Marymount Manhattan College, New York, New York, USA.

${ }^{3}$ Department of Geosciences, Princeton University, Princeton, New Jersey, USA.

${ }^{4}$ Advanced Light Source, Lawrence Berkeley National Laboratory, Berkeley, California, USA.

${ }^{5}$ Consortium for Advanced Radiation Sources, University of Chicago, Chicago, Illinois, USA.

${ }^{6}$ Department of Marine Chemistry and Geochemistry, Woods Hole Oceanographic Institution, Woods Hole, Massachusetts, USA.

${ }^{7}$ Earth Sciences Division, Lawrence Berkeley National Laboratory, Berkeley, California, USA.

Copyright 2010 by the American Geophysical Union. 0886-6236/10/2010GB003794
}

consumer products and now have a global environmental distribution, with bioaccumulation through the food chain [Darnerud, 2003; Norstrom et al., 2002; Santillo and Johnston, 2003]. Environmental bromine (Br) is thought to exist as inorganic bromide $\left(\mathrm{Br}_{\text {inorg }}\right)$, in the $-\mathrm{I}$ oxidation state. $\mathrm{Br}_{\text {inorg }}$ is presumed sufficiently unreactive for use as a conservative tracer in hydrological studies [Simmons et al., 1992; Tanner and Sukias, 1995; Weaver et al., 2003].

[3] However, $\mathrm{Br}_{\text {inorg }}$ can convert to $\mathrm{Br}_{\text {org }}$ via natural mechanisms, through abiotic [Keppler et al., 2000; Pelizzetti and Calza, 2002] and enzymatic [Butler and Carter-Franklin, 2004; Theiler et al., 1978] pathways. Marine organisms in particular are known to synthesize a variety of low molecular weight $\mathrm{Br}_{\text {org }}$ molecules, including bromoalkanes, bromoketones, bromopyrroles, bromophenols, bromophycolides, and PBDE analogs, as probable means of chemical defense [Dembitsky, 2002; Gribble, 2000; La Barre et al., 2010; Lane et al., 2009; Laturnus et al., 2000; Wever et al., 1991]. Several naturally produced volatile bromocarbons have been linked to stratospheric ozone depletion [Carpenter and Liss, 2000; Quack et al., 2004]. Approximately 2000 natural $\mathrm{Br}_{\text {org }}$ 
compounds have been identified, the majority of marine origin [Gribble, 2003], but the fate of natural $\mathrm{Br}_{\mathrm{org}}$ in the water column and sedimentary environment remains largely unexplored. In fact, the classification of $\mathrm{Br}$ as a conservative element in seawater [Morris and Riley, 1966] has endured for decades.

[4] Several studies have provided clues that $\mathrm{Br}$ does not exist exclusively as $\mathrm{Br}_{\text {inorg }}$ in marine sediments by revealing strong correlations between total $\mathrm{Br}$ and organic carbon $\left(\mathrm{C}_{\text {org }}\right)$ concentrations in sediment columns [Mayer et al., 1981; Price et al., 1970; Pruysers et al., 1991; Tenhaven et al., 1988; Ziegler et al., 2008]. Tellingly, total $\mathrm{Br}$ has been found to be enriched in the upper portions of sediment cores from the Antarctic coast [Santos et al., 2007]. These oceanographic studies did not explore the chemical speciation of $\mathrm{Br}$ in the sediments and drew no clear conclusions about the molecular basis for the observations. Few efforts have been made to probe the dynamics of $\mathrm{Br}$ in the environment, and thus, the paradigmatic classification of marine $\mathrm{Br}$ as conservative $\mathrm{Br}_{\text {inorg }}$ persists. The scarcity of research in this area may be partly attributable to the disciplinary disconnect between the oceanographic studies that examine elemental profiles in sediments and the natural products chemistry or ecological studies that typically report discoveries of biogenic $\mathrm{Br}_{\text {org }}$ molecules.

[5] Elucidating the chemical speciation of $\mathrm{Br}$ associated with $\mathrm{C}_{\text {org }}$ in environmental samples presents exceptional challenges due to the complex macromolecular structure of natural organic matter (NOM). The existence of high molecular weight brominated NOM in sediments has been proposed based on detection of brominated degradation products [Johansson et al., 1994] and the "adsorbable organohalogen" (AOX) sum parameter, following reaction with activated carbon [Müller et al., 1996]. A recently developed technique relies on combustion followed by ion chromatography to measure the concentrations of organohalogens in peat samples [Putschew et al., 2003]. This method was used to demonstrate the formation of $\mathrm{Br}_{\text {org }}$ during humification in terrestrial peat bogs and show that more than $90 \%$ of $\mathrm{Br}$ in these environments is bonded to carbon [Biester et al., 2006, 2004]. Degradative techniques, however, are prone to induce chemical alterations in natural samples, while the AOX assay does not distinguish among halogens and is subject to interferences from inorganic halides and nonhalogenated organic molecules [Berger, 1984; Harper, 1984].

[6] In order to investigate the role of different sedimentary systems as sinks of naturally produced $\mathrm{Br}_{\text {org }}$, we used synchrotron-based X-ray spectroscopic and spectromicroscopic techniques to probe $\mathrm{Br}$ distribution and speciation in coastal and deep marine sediments. These element-specific methods remove the risks of incomplete extraction or chemical alterations of samples. $\mathrm{Br}_{\text {org }}$ was detected at various concentrations in all sediments examined, including those from (1) deep marine systems [Bower's Ridge, Bering Sea; northern continental shelf, Bering Sea; the Antarctic Zone in the west Pacific sector of the Southern Ocean] and (2) coastal and estuarine systems [Barnegat Bay, NJ, USA; Cape Cod, MA, USA]. For several of the coastal and marine systems, chemical profiles were established as a function of sediment column depth, shedding light on the biogeochemical cycling of $\mathrm{Br}$.

\section{Materials and Methods}

\subsection{Sample Details}

\subsubsection{Coastal and Deep Sea Sediments}

[7] Sediment cores $(30.5 \mathrm{~cm}$ depth, $5.1 \mathrm{~cm}$ diameter; stainless steel AMS soil core sampler, American Falls, ID) were taken from coastal sites in Barnegat Bay, NJ, and Cape Cod, MA. Cores were collected in removable butyrate plastic retaining liners and secured with polyethylene liner caps. In the laboratory, cores were stored horizontally at $4{ }^{\circ} \mathrm{C}$ until further processing. For quantitative analysis of $\mathrm{Br}_{\text {org }}$ and $\mathrm{Br}_{\text {inorg }}$ species, intact cores were divided into horizontal sections of $3-5 \mathrm{~cm}$ in height using a Dremel ${ }^{\mathrm{TM}}$ saw. Portions of these sediment sections were set aside at $4^{\circ} \mathrm{C}$, still wet, for $\mathrm{Br}$ speciation analysis by $\mathrm{X}$-ray absorption spectroscopy. For total $\mathrm{Br}$ quantification, the remainder of the sediment material was air-dried over several days before pulverization with a mortar and pestle. The resulting powder was mixed with a cohesive matrix material, $\mathrm{NaNO}_{3}(\sim 150 \mathrm{mg}$ sediment $+\sim 250 \mathrm{mg} \mathrm{NaNO}_{3}$ ). Pellets were formed from this mixture using a $13 \mathrm{~mm}$ die with tungsten carbide anvils beneath 10 tons of pressure in a standard hydraulic laboratory press. For X-ray spectromicroscopic analysis of elemental distributions, cores were brought intact to the synchrotron beamline, where the butyrate plastic core liner was sliced open vertically with the Dremel ${ }^{\mathrm{TM}}$ saw and sections of the core were delicately removed and mounted with minimal disturbance of the sediment grains.

[8] Wet, presectioned, mixed sediment subsamples from Bering Sea and Southern Ocean cores were provided courtesy of D. Sigman (Department of Geosciences, Princeton University; refer to Lehmann et al. [2005] for geographical and sampling details on the Bering Sea northern continental shelf "MC5" and Bower's Ridge "MC24" samples and Robinson et al. [2004] for details on the Southern Ocean "MC4" samples). These sediments were analyzed in situ for $\mathrm{Br}$ speciation by X-ray absorption spectroscopy and elemental distribution by X-ray spectromicroscopy. For total $\mathrm{Br}$ quantification, sediments were freeze-dried, pulverized, and pelletized as described previously [Leri et al., 2006]. To assess the solubility of $\mathrm{Br}$ species, two MC24 samples $(2-3 \mathrm{~cm}$ and $18-19 \mathrm{~cm})$ were analyzed before and after vigorous rinsing with deionized water.

\subsubsection{Sinking Particulates From Water Column Sediment Traps}

[9] Dry, elutriated particulates from the water column in the Sea of Okhotsk were provided by D. Sigman (Department of Geosciences, Princeton University). This material was collected in sediment traps deployed at 258 and $1061 \mathrm{~m}$ every few months over the course of a cruise in 1990-1991 [Honda et al., 1997]. Dry, elutriated particulates from the water column in the Ligurian Sea were provided by C. Lee (Marine Sciences Research Center, SUNY Stony Brook). This material was collected in sediment traps deployed at $200 \mathrm{~m}$ in May 2004 [Goutx et al., 2007]. In both cases, the quantities of sediment trap material available were insuffi- 
cient to allow total $\mathrm{Br}$ quantification, but the samples were subjected to qualitative $\mathrm{Br}$ speciation and elemental distribution analyses.

\subsection{Quantification of $\mathbf{B r}_{\text {org }}$ and $\mathbf{B r}_{\text {inorg }}$}

[10] A novel quantitative method described previously [Leri et al., 2006] was used to measure absolute $\mathrm{Br}_{\text {org }}$ and $\mathrm{Br}_{\text {inorg }}$ concentrations in sediment samples through a combination of X-ray fluorescence (XRF) and $\mathrm{Br} 1 s$ X-ray absorption near-edge structure (XANES) spectroscopies. $\mathrm{Br}$ 1s XANES spectroscopy was performed at beamline X23A2 at the National Synchrotron Light Source (NSLS, Brookhaven National Laboratory, Upton, NY) and at beamline 4-3 at the Stanford Synchrotron Radiation Laboratory (SSRL, Stanford Linear Accelerator Center, Menlo Park, CA). For total $\mathrm{Br}$ concentration measurements, $\mathrm{Br} \mathrm{K} \alpha$ emission spectra were collected at NSLS beamline X26A.

\subsection{X-ray Microanalysis and $\mathrm{Br} 1 s \mu \mathrm{m}$-XANES Spectroscopy}

[11] The micron $(\mu \mathrm{m})$ scale distribution and speciation of $\mathrm{Br}$ were established in heterogeneous natural samples using synchrotron-based X-ray spectromicroscopic techniques involving (1) $\mu \mathrm{m}$-scale X-ray fluorescence ( $\mu$-XRF) imaging of elemental distributions and (2) establishment of $\mathrm{Br}$ speciation through $\mu$-XANES spectroscopy using a focused beam [Bertsch and Hunter, 2001]. X-ray spectromicroscopic studies were performed on beamline 10.3.2 [Marcus et al., 2004] at the Advanced Light Source (ALS, Lawrence Berkeley National Laboratory, Berkeley, CA).

[12] Sediment samples were analyzed with no chemical preparation, mounted between X-ray clean polyfilm and Kapton tape on metal alloy sample holders designed to fit the movable stage in the X-ray beam path. The polyfilmcovered side of the sample was exposed to the incoming beam at a $45^{\circ}$ angle. The seven-element Ge detector was oriented at $90^{\circ}$ from the X-ray beam in the plane of the sample. Micro-XRF elemental distribution maps were acquired at $16 \mu \mathrm{m}^{2}$ resolution by training the microfocused $\mathrm{X}$-ray beam on the sample while the stage moved in the horizontal and vertical directions. The X-ray beam was set to the maximum size available at the focus of the beamline, 16 (horizontal) $\times 7$ (vertical) $\mu \mathrm{m}^{2}$. Fluorescence counts were collected exciting at $14 \mathrm{keV}$, producing image "maps" of select elemental distributions, including $\mathrm{Br}, \mathrm{Zn}, \mathrm{Cu}, \mathrm{Ni}, \mathrm{Co}$, $\mathrm{Fe}, \mathrm{Mn}, \mathrm{Ti}$, and $\mathrm{Ca}$. Micro-XRF maps were processed using the XY-mapping software associated with beamline 10.3.2. Cross correlations between $\mathrm{Br}$ and other elements were deduced quantitatively through Pearson-like, pixel-bypixel comparison of the two elements' $\mu$-XRF maps. The resulting Pearson $r$ correlation coefficient quantifies the degree to which two elemental distributions are related, either inversely or directly, with a range of -1.00 to +1.00 .

[13] To explore the spatial variability of $\mathrm{Br}$ speciation, areas of interest on the $\mu$-XRF maps were probed via $\mathrm{Br} 1 s$ $\mu$-XANES spectroscopy. For $\mathrm{Br} 1 s \mu$-XANES spectra, sample fluorescence was measured over an energy range of 13,415 to $13,550 \mathrm{eV}$. Spectra were acquired using a $0.6 \mathrm{eV}$ step size around the $K$ absorption edge and $0.9-2.5 \mathrm{eV}$ step sizes above and below the edge. Dwell times at each point were set to at least $3 \mathrm{~s}$; the monochromator was allowed to settle for $0.5 \mathrm{~s}$ between steps. The energy of the monochromator was calibrated to the inflection point in the $\mathrm{Br} 1 \mathrm{~s}$ XANES spectrum of solid $\mathrm{KBr}$, defined at $13,474 \mathrm{eV}$. The precise value of the inflection point was determined from the maximum of the first derivative of the spectrum.

[14] $\mathrm{Br} 1 s \mu$-XANES data were processed using EXAFS Editor and WinXAS version 2.0 [Ressler, 1998]. EXAFS Editor, a data analysis utility associated with beamline 10.3.2, was used for preliminary inspection, dead time correction, and averaging of fluorescence scans. Averaged scans were imported into WinXAS for energy calibration, background subtraction, and normalization. A smooth background was obtained by fitting a first-order polynomial to the preedge region, and the edge jump was normalized to 1.0 with another first-order polynomial fit to the postedge region. This normalization allows for comparative analysis of spectral features in the near-edge region, where absorption intensity is dependent on Br speciation. WinXAS was also used for nonlinear least squares fitting of sample spectra with data from $\mathrm{Br}$-containing standards to establish the speciation of $\mathrm{Br}$.

\subsection{Quantification of $\mathbf{C}_{\text {org }}$}

[15] $\mathrm{C}_{\text {org }}$ concentrations in sediment samples were measured using an autosampler-equipped Carlo Erba NA-1500 Elemental Analyzer (CE Elantech, Lakewood, NJ). Carbonate was removed from preweighed sediments prior to analysis by acidification with excess $5 \% \mathrm{H}_{2} \mathrm{SO}_{3}$. Acidified samples were weighed into precombusted tin boats with excess tin powder to promote oxidation. Acetanilide $\left(\mathrm{C}_{8} \mathrm{H}_{9} \mathrm{NO}\right)$ was used as a calibration standard.

\section{Results and Discussion}

\subsection{Br 1s XANES Spectroscopy}

[16] Drawing on synchrotron radiation, XANES spectroscopy is sensitive to the bonding state of $\mathrm{Br}$, allowing distinctions to be drawn between $\mathrm{Br}_{\text {inorg }}$ and $\mathrm{Br}_{\text {org }}$ species in natural samples without subjecting them to procedures that amplify the risk of inadvertent bromination or incomplete recoveries.

[17] The intense increase in X-ray absorption around $13,474 \mathrm{eV}$ (the $\mathrm{Br} K$ absorption edge) and the spectral features in the near-edge region correspond to electronic transitions from the $\mathrm{Br}-1 s$ shell to empty atomic and molecular orbitals of $\mathrm{Br}-4 p$ character. For $\mathrm{Br}_{\text {inorg }}$ compounds, the energy of the $\mathrm{Br}$ transition shifts to higher values with an increase in $\mathrm{Br}$ oxidation state. For example, $\mathrm{Br}(\mathrm{V})$ in sodium bromate (Figure 1, spectrum d) exhibits an absorption maximum at 13,478.1, whereas $\operatorname{Br}(-\mathrm{I})$ in aqueous $\mathrm{KBr}$ (Figure 1, spectrum c) absorbs at 13,477.3 eV. (Energy values are arbitrary, quoted for illustration of relative differences.) By contrast, $\mathrm{Br}_{\text {org }}$ compounds give rise to discrete low-energy peaks around 13,473 eV, as in 4-bromophenol (Figure 1, spectrum a) and 1-bromoeicosane (Figure 1, spectrum b). These sharp features correspond to the $1 \mathrm{~s} \rightarrow \pi^{*}$ or $\sigma^{*}$ transitions associated with the $\mathrm{C}-\mathrm{Br}$ bonds and differ slightly in absorption 

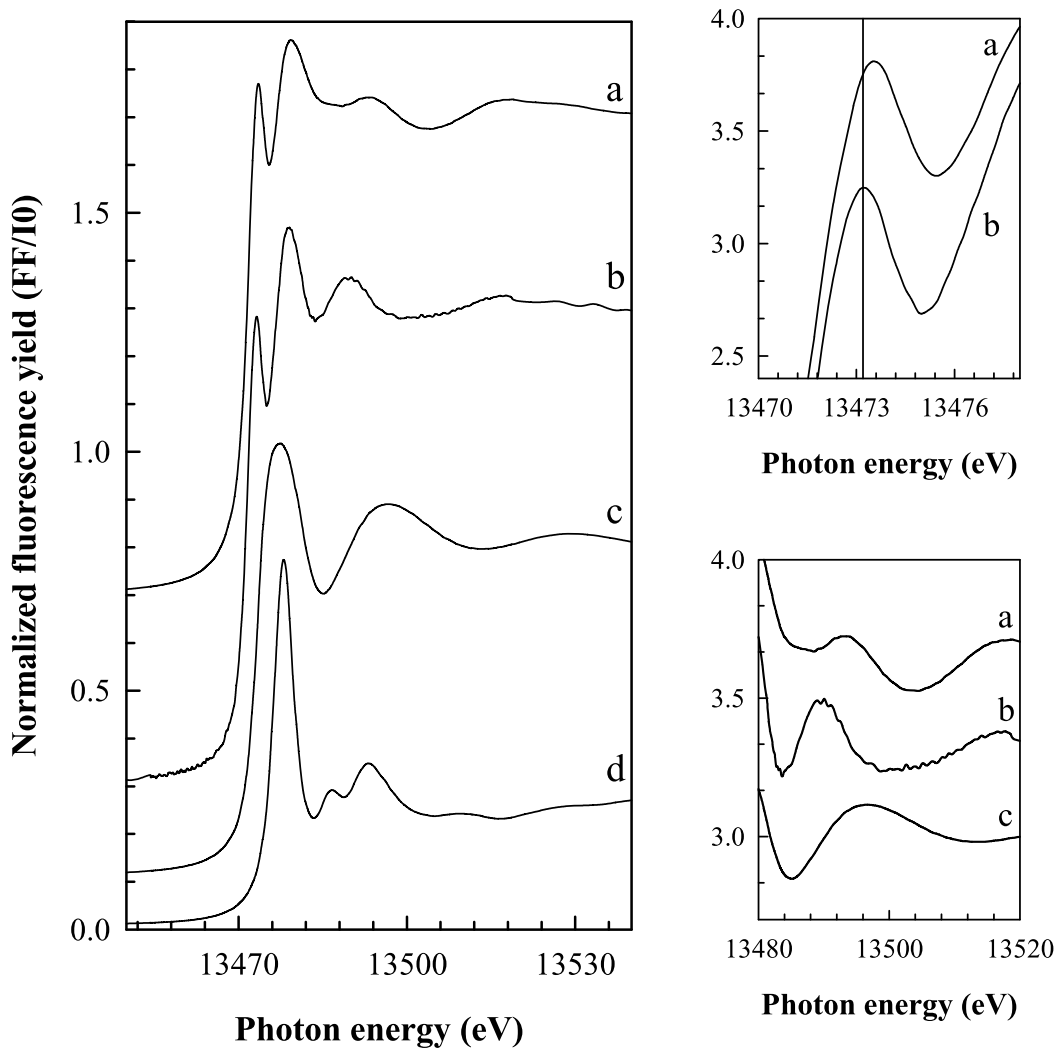

Figure 1. (left) Normalized $\mathrm{Br} 1 s \mathrm{X}$-ray absorption near-edge structure (XANES) spectra of model compounds: spectrum a, 4-bromophenol; spectrum b, 1-bromoeicosane; spectrum c, $\mathrm{KBr}(\mathrm{aq})$, amplitude $\times 0.7$; spectrum d, sodium bromate, amplitude $\times 0.25$. (top right) Amplitudes enhanced $3 X$. (bottom right) Amplitudes of spectra $a$ and $b$ enhanced $3 X$.

energy depending on the $\mathrm{C}-\mathrm{Br}$ bond length, as becomes evident through comparison of the aliphatic (bromoeicosane) and aromatic (bromophenol) $\mathrm{Br}_{\text {org }}$ standards (Figure 1, top right). Postedge features also vary depending on the coordination environment of $\mathrm{Br}$ (Figure 1, bottom right). $\mathrm{X}$-ray absorption fine structure features have been theoretically modeled to shed light on the molecular structure of brominated pollutants [Bergknut et al., 2008].

[18] The substantial spectral variations depending on the oxidation state and coordination environment of $\mathrm{Br}$ allow the relative contributions of $\mathrm{Br}_{\text {inorg }}$ and $\mathrm{Br}_{\text {org }}$ to total $\mathrm{Br}$ in natural sample spectra to be estimated via least squares fitting with spectra of representative model compounds. However, while $\mathrm{Br} 1 s$ XANES spectroscopy illuminates the local coordination environment of $\mathrm{Br}$, it offers little information on the comprehensive size and structure of $\mathrm{Br}$-containing molecules in the natural samples.

\subsection{Geochemistry of $\mathrm{Br}$ as a Function of Sediment Depth and $\mathrm{C}_{\text {org }}$ Content}

[19] Chemical profiles of coastal and marine sediment cores reveal the variation of $\mathrm{Br}_{\text {org }}$ concentration as a function of sediment depth and NOM content (Table 1). In opal-rich Southern Ocean Antarctic sediments composed of Holocene diatomaceous ooze [Robinson et al., 2004], Br speciation changes from $\mathrm{Br}_{\text {org }}$ - to $\mathrm{Br}_{\text {inorg }}$-dominated going from 0 to $16 \mathrm{~cm}$ down the sediment column (Figure 2). This transformation is signaled in the spectra by the narrowing and amplification of the main $\mathrm{Br} 1 s$ XANES transition, with the disappearance of the $\mathrm{Br}_{\text {org }}$ shoulder (Figure 2a). The $\mathrm{Br}_{\text {inorg }}$ appears in aqueous form, resembling the $\mathrm{KBr}$ (aq) standard (compare Figure 2a, spectrum e, with Figure 1, spectrum c). The absolute $\mathrm{Br}_{\text {org }}$ concentration decreases sharply below the sediment-water interface, falling below the detection limit $(<1 \mathrm{ppm})$ by $14-16 \mathrm{~cm}$ (Figure $2 \mathrm{~b})$. The $\mathrm{C}_{\text {org }}$ concentration also declines with depth, though less precipitously than $\mathrm{Br}_{\text {org }}$ (Figure $2 \mathrm{~b}$ ). The decrease in the $\mathrm{Br}_{\text {org }}: \mathrm{C}_{\text {org }}$ ratio with sediment depth (Table 1) suggests that the $\mathrm{Br}_{\text {org }}$ in these sediments constitutes a relatively labile fraction of NOM.

[20] Comparable trends appear in sediments from the Bering Sea sampling site located at the base of the northern continental shelf, at a water depth of $3349 \mathrm{~m}$ (Figure 3). Total $\mathrm{Br}$ concentrations at this location are lower than those in the Antarctic sediments (Table 1), possibly because the Bering Sea is less saline than the open ocean and/or because the sediments have a larger fraction of terrestrially derived $\mathrm{NOM}$, which originates under lower background $\mathrm{Br}$ concentrations. The sediments are rich in $\mathrm{C}_{\text {org }}$, likely owing to 
Table 1. Br Speciation, Concentration, and Total Organic Carbon in Sediments ${ }^{\mathrm{a}}$

\begin{tabular}{|c|c|c|c|c|c|}
\hline $\begin{array}{l}\text { Depth Below } \\
\text { Sediment-Water } \\
\text { Interface }(\mathrm{cm})\end{array}$ & $\begin{array}{r}\mathrm{Br}_{\text {inorg }} \\
(\mathrm{ppm})\end{array}$ & $\begin{array}{l}\mathrm{Br}_{\text {org }} \\
(\mathrm{ppm})\end{array}$ & $\begin{array}{l}\text { Total }[\mathrm{Br}] \\
\quad(\mathrm{ppm})\end{array}$ & $\begin{array}{c}\text { Total }\left[\mathrm{C}_{\text {org }}\right] \\
(\mathrm{g} / \mathrm{kg})\end{array}$ & $\begin{array}{l}\mathrm{Br}_{\text {org }}: \mathrm{C}_{\text {org }} \\
\text { Ratio/ } 10^{-3}\end{array}$ \\
\hline \multicolumn{6}{|c|}{ Antarctic Pacific } \\
\hline $0-0.5$ & 201 & 108 & 309 & ND & ND \\
\hline $0.5-1$ & 108 & 36 & 144 & $5.5 \pm 0.1$ & 6.5 \\
\hline $2-2.5$ & 126 & 14 & 140 & $4.3 \pm 0.2$ & 3.3 \\
\hline $7-8$ & 190 & 10 & 200 & $3.3 \pm 0.2$ & 3.0 \\
\hline $14-16$ & 130 & $<1$ & 130 & $2.6 \pm 0.1$ & UD \\
\hline \multicolumn{6}{|c|}{ Bering Sea (Northern Continental Shelf) } \\
\hline 2 & 91 & 59 & 150 & $13.1 \pm 0.1$ & 4.5 \\
\hline 7 & 79 & 60 & 139 & $12.0 \pm 0.3$ & 5.0 \\
\hline 13 & 66 & 28 & 94 & $11.7 \pm 0.3$ & 2.4 \\
\hline 19 & 83 & 28 & 111 & $10.8 \pm 0.1$ & 2.6 \\
\hline \multicolumn{6}{|c|}{ Bering Sea (Bower's Ridge) } \\
\hline $2-3$ & 162 & 8 & 170 & ND & ND \\
\hline $4-5$ & 118 & 6 & 124 & $7.2 \pm 0.1$ & 0.8 \\
\hline $8-9$ & 52 & 42 & 94 & $8.9 \pm 0.1$ & 4.7 \\
\hline $18-19$ & 29 & 16 & 45 & $8.7 \pm 0.9$ & 1.8 \\
\hline $28-29$ & 27 & 33 & 60 & $18.0 \pm 0.8$ & 1.8 \\
\hline $34-35$ & 71 & 47 & 118 & $10.9 \pm 0.4$ & 4.3 \\
\hline \multicolumn{6}{|c|}{ Cape Cod, MA, Estuary } \\
\hline $0-3.5$ & 12 & 18 & 30 & $4.3 \pm 0.8$ & 4.2 \\
\hline $4-9$ & 7 & 3 & 10 & $0.9 \pm 0.2$ & 3.3 \\
\hline $9-16$ & 8 & 3 & 11 & $1.1 \pm 0.3$ & 2.7 \\
\hline $16-20$ & 7 & 3 & 10 & $0.4 \pm 0.1$ & 7.5 \\
\hline $20-25$ & 8 & $<1$ & 8 & $0.3 \pm 0.1$ & UD \\
\hline \multicolumn{6}{|c|}{ Barnegat Bay, NJ } \\
\hline $\begin{array}{l}\text { 7-9 } \mathrm{cm} \text { (organic } \\
\text { lens included) }\end{array}$ & 4 & 2 & 6 & $0.7 \pm 0.1$ & 2.9 \\
\hline
\end{tabular}

${ }^{\mathrm{a}} \mathrm{ND}$, not determined; UD, undefined.

the high biological productivity characteristic of the Bering Sea continental shelf, in combination with the physical characteristics of the steep slope channeling large quantities of NOM into the sediments below [Lehmann et al., 2005]. The $\mathrm{C}_{\text {org }}$ concentration decreases steadily with sediment depth but remains high even at $>10 \mathrm{~cm}$, which may account for the greater $\mathrm{Br}_{\text {org }}$ concentrations relative to the Antarctic sediments at similar depths (Table 1). At the Bering Sea northern continental shelf site, the $\mathrm{Br}_{\text {org }}: \mathrm{C}_{\text {org }}$ ratio plunges dramatically at deeper depths, again suggesting that the $\mathrm{Br}_{\text {org }}$ component is a comparatively labile form of NOM.

[21] These observations resonate with recent findings in sediments from coastal Louisiana, where increasing total $\mathrm{Br}$ concentrations were used as a proxy for increasing content of marine (as opposed to terrestrially) derived NOM [Mayer et al., 2007]. In the Louisiana sediments, the total $\mathrm{Br}: \mathrm{C}_{\text {org }}$ ratio decreases with sediment depth, which the authors interpreted as enhanced degradation of the marine fraction of NOM during diagenesis.

[22] Sediments from Bower's Ridge in the Bering Sea (water depth $\sim 714 \mathrm{~m}$ ) deviate from the $\mathrm{Br}$ geochemical patterns described above. In these sediments, $\mathrm{Br}$ speciation is dominated by $\mathrm{Br}_{\text {inorg }}$ near the sediment-water interface and $\mathrm{Br}_{\text {org }}$ at sediment depths of $>8 \mathrm{~cm}$ (Figure $4 \mathrm{a}$ ). In these sediments, $\mathrm{Br}_{\text {org }}$ concentration fluctuates and increases overall down the $35 \mathrm{~cm}$ sediment column, as does $\mathrm{C}_{\text {org }}$ concentration (Figure 4c). The increasing NOM content with depth is most likely attributable to the low sedimentation rates at this location, which make the effects of past deglaciation apparent at shallow depths in relation to other cores [Cook et al., 2005].
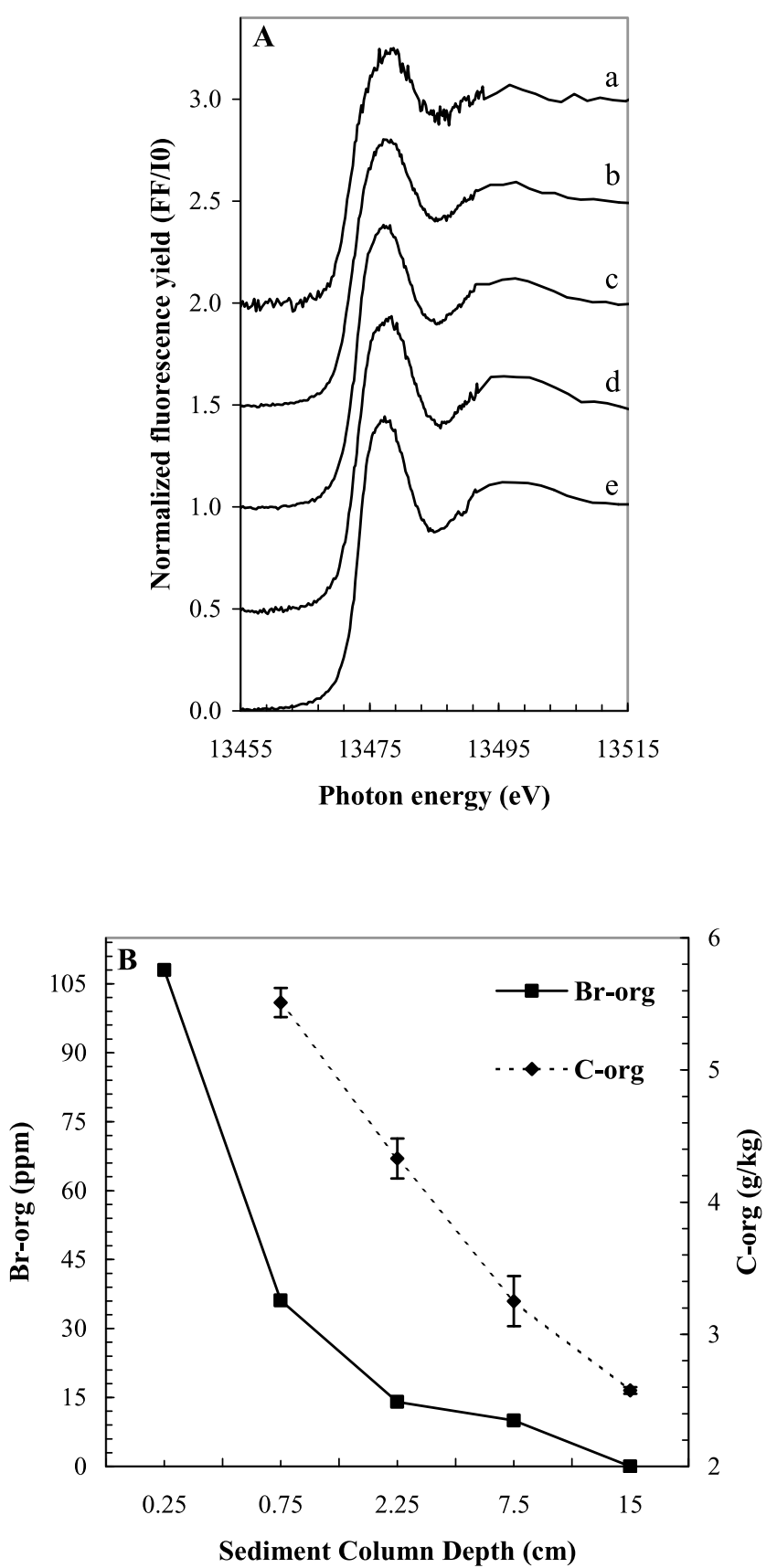

Figure 2. Data from homogenized Antarctic Pacific sediment sections. (a) Variation in $\mathrm{Br}$ speciation with sediment column depth. Normalized $\mathrm{Br} 1 s$ bulk XANES spectra: spectrum a, 0-0.5 cm; spectrum b, 0.5-1 cm; spectrum c, 2$2.5 \mathrm{~cm}$; spectrum d, 7-8 cm; spectrum e, 14-16 cm. (b) Relationships between depth, $\mathrm{Br}_{\text {org }}$ and $\mathrm{C}_{\text {org }}$, concentrations. 

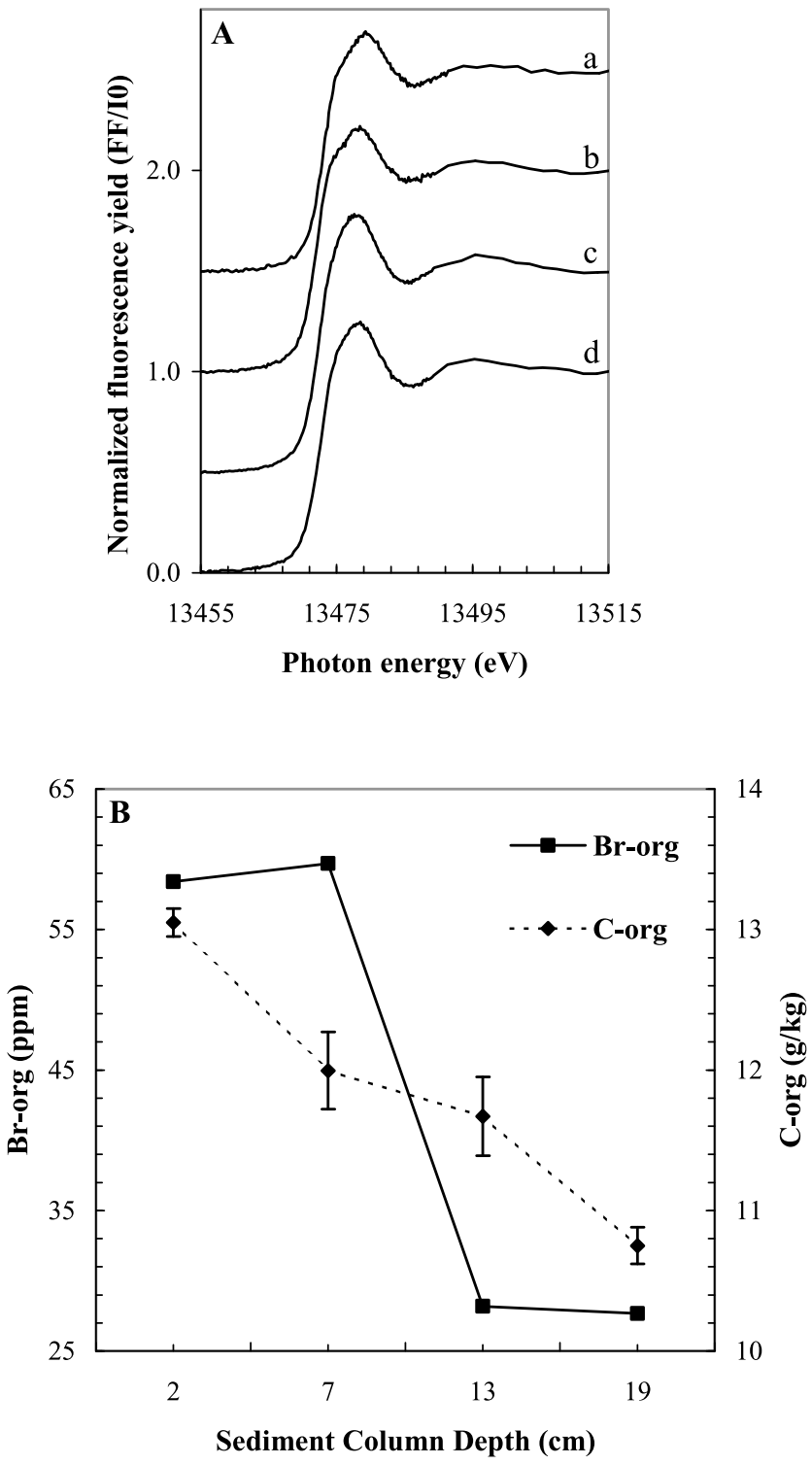

Figure 3. Data from homogenized Bering Sea (northern continental shelf) sediment sections. (a) Variation in $\mathrm{Br}$ speciation with sediment column depth. Normalized $\mathrm{Br} 1 s$ bulk XANES spectra: spectrum a, $2 \mathrm{~cm}$; spectrum $\mathrm{b}, 7 \mathrm{~cm}$; spectrum c, $13 \mathrm{~cm}$; spectrum d, $19 \mathrm{~cm}$. (b) Relationships between depth, $\mathrm{Br}_{\text {org }}$, and $\mathrm{C}_{\text {org }}$ concentrations.

[23] Rinsing Bower's Ridge sediments with deionized water easily removes $\mathrm{Br}_{\text {inorg }}$, revealing strong $\mathrm{Br}_{\text {org }}$ transitions in samples from shallow and deep sections of the core (Figure $4 \mathrm{~b}$ ). This indicates that $\mathrm{Br}_{\text {inorg }}$ exists in a soluble form, probably inhabiting sediment pore waters. The $\mathrm{Br}_{\text {org }}$ revealed in the XANES signal after rinsing may form part of macromolecular sediment NOM or else undergo strong sorption interactions in the sediments, making it resistant to removal by vigorous aqueous rinsing.

[24] In estuarine sediments from Cape Cod, MA, Br displays geochemical trends similar to those observed in the
Antarctic and Bering Sea continental shelf sediments. $\mathrm{Br}_{\text {inorg }}$ accounts for an increasing proportion of total $\mathrm{Br}$ with depth in the $25 \mathrm{~cm}$ sediment column (Figure $5 \mathrm{a}$ ). $\mathrm{Br}_{\text {org }}$ concentration decreases sharply below the sediment-water interface, closely paralleling the drop in $\mathrm{C}_{\text {org }}$ (Figure $5 b$ ).

[25] This investigation of $\mathrm{Br}$ geochemistry as a function of depth and NOM content reveals a general correlation between $\mathrm{Br}_{\text {org }}$ and $\mathrm{C}_{\text {org }}$ in estuarine and marine sediments. In most of the locations examined, $\mathrm{Br}$ speciation changes with sediment depth from $\mathrm{Br}_{\text {org }}$ - to $\mathrm{Br}_{\text {inorg }}$-dominated, and both $\mathrm{Br}_{\text {org }}$ and $\mathrm{C}_{\text {org }}$ concentrations decrease with depth. In the anomalous case of the Bower's Ridge sediments, $\mathrm{Br}$ speciation changes from $\mathrm{Br}_{\text {inorg }}$ - to $\mathrm{Br}_{\text {org }}$-dominated with depth. However, the resemblance in fluctuation patterns of $\mathrm{Br}_{\text {org }}$ and $\mathrm{C}_{\text {org }}$ concentrations with depth in the Bower's Ridge sediments appears sufficient to uphold the general correlation between $\mathrm{Br}_{\text {org }}$ and $\mathrm{C}_{\mathrm{org}}$. In the marine environments, the $\mathrm{C}_{\text {org }}-\mathrm{Br}_{\text {org }}$ correlations are imperfect, which could be attributable to variable sources of NOM in the sediments, with multiple types of $\mathrm{Br}_{\text {org }}$ produced through different biotic and abiotic pathways.

\subsection{Spatial Distribution of $\mathrm{Br}$ and Correlations of $\mathrm{Br}$ With Other Elements}

[26] High-resolution spectromicroscopic images of $\mathrm{Br}$ distribution in undisturbed sediment core sections reveal a spatial correlation between $\mathrm{C}_{\text {org }}$ and $\mathrm{Br}_{\text {org }}$ that reinforces the association apparent in the bulk measurements. Sediment cores from shallow waters in Barnegat Bay, NJ, exhibit distinct "lenses" of dark-colored NOM approximately $8 \mathrm{~cm}$ below the sediment-water interface. The organic lenses coincide with areas of radically elevated $\mathrm{Br}$ concentration (Figure 6a). $\mathrm{Br} 1 s \mu$-XANES spectra reveal the $\mathrm{Br}$ associated with $\mathrm{NOM}$ to exist as $\mathrm{Br}_{\text {org }}$, with strong $\mathrm{Br}_{\text {org }}$ transitions characterizing spectra acquired within the region of the organic lens (Figure $6 \mathrm{c}$, spectra $\mathrm{b}$ and $\mathrm{c}$ ). By contrast, in areas of dilute $\mathrm{Br}$ concentration in the sediment, spatially removed from the organic lens, $\mathrm{Br}$ speciation is inorganic (Figure 6c, spectrum a). Such images provide a dramatic illustration of $\mathrm{Br}$ enrichment and fractionation in areas of high NOM content. Homogenization of the sediment section analyzed in Figure 6 resulted in a bulk $\mathrm{Br}$ speciation measurement of $65 \% \mathrm{Br}_{\text {inorg }}$ and $35 \% \mathrm{Br}_{\text {org }}$ (Figure 6c, spectrum d).

[27] The correlation of $\mathrm{C}_{\text {org }}$ and $\mathrm{Br}_{\text {org }}$ is substantiated by the coincidence of $\mathrm{NOM}$ and $\mathrm{Br}_{\text {org }}$ with metal cations. An example of such associations becomes qualitatively manifest through comparison of the fluorescence images of $\mathrm{Br}$ and $\mathrm{Fe} / \mathrm{Mn}$ in the New Jersey bay sediment section (Figures 6a and $6 \mathrm{~b}$ ). The coincidence of elevated $\mathrm{Fe} / \mathrm{Mn}$ concentrations with the organic lens could result from sorption interactions between metal cations and NOM. The $\mu$-XRF maps do not indicate whether these metals are in the mineral phase, but in principle they could form authigenic oxide phases in decaying organic aggregates during diagenesis. Strong cross correlations between $\mathrm{Br}$ and numerous cations, including $\mathrm{Zn}, \mathrm{Fe}, \mathrm{Mn}, \mathrm{Ni}$, and $\mathrm{Ca}$, were calculated through Pearson-like analysis of spatial elemental distributions in the sediment, though the calculations likely exhibit some bias toward 

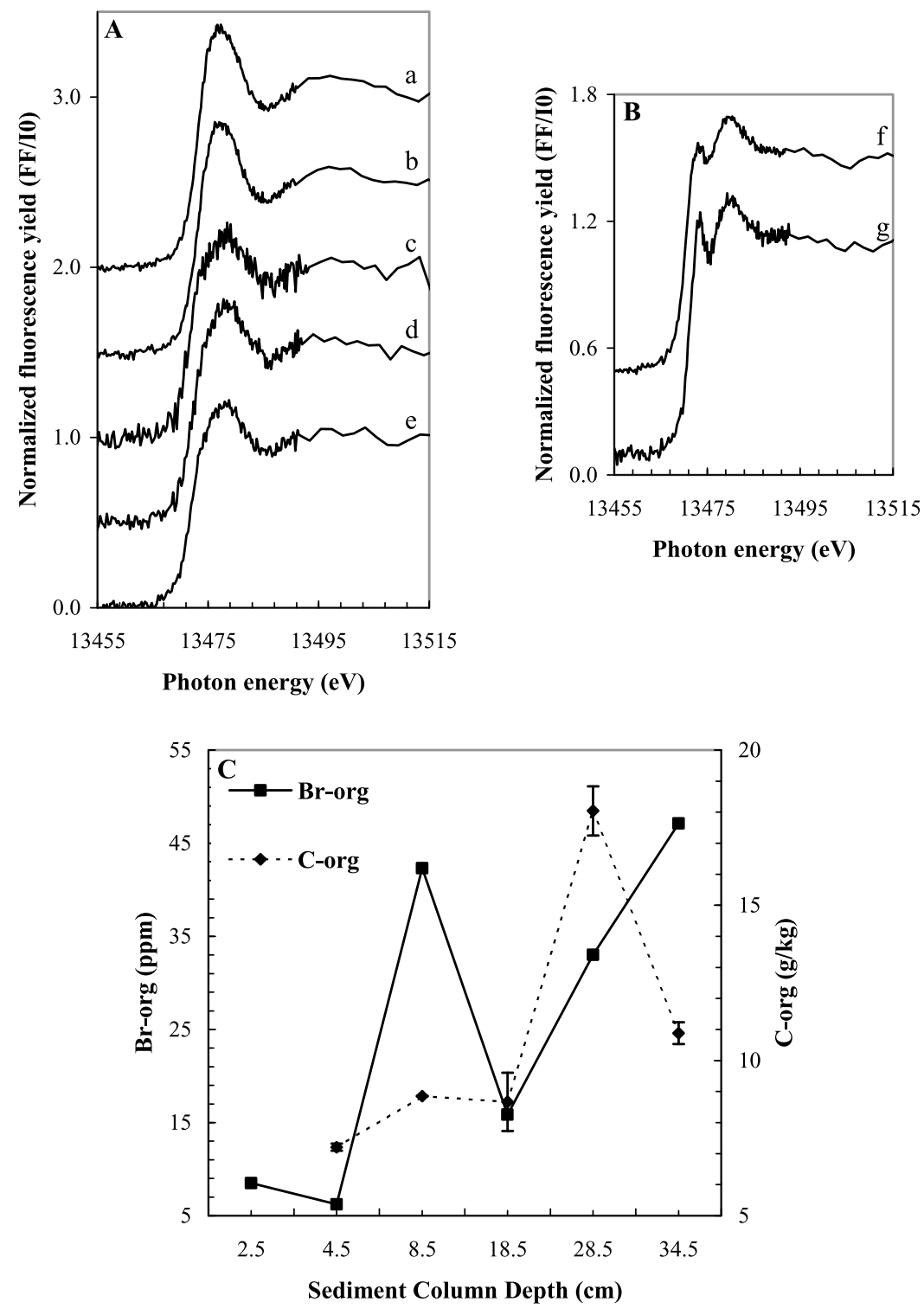

Figure 4. Data from homogenized Bering Sea (Bower's Ridge) sediment sections. (a and b) Variation in Br speciation with sediment column depth. Normalized Br $1 s$ bulk XANES spectra: spectrum a, 2-3 cm; spectrum b, 4-5 cm; spectrum c, 8-9 cm; spectrum d, 18-19 cm; spectrum e, 34-35 cm; spectrum f, 2-3 cm (rinsed); spectrum g, 18-19 cm (rinsed). (c) Relationships between depth, $\mathrm{Br}_{\text {org }}$ and $\mathrm{C}_{\text {org }}$ concentrations.

positive correlations due to the irregular density of the sediment surface (see auxiliary material). ${ }^{1}$

[28] The spatial distribution and $\mu$-speciation of $\mathrm{Br}$ in sediments undergo striking changes with depth. Close to the sediment-water interface in undisturbed Cape Cod estuarine sediments, $\mathrm{Br}$ distribution is highly heterogeneous, concentrated in nebulous aggregates spanning several $\mathrm{mm}^{2}$ (Figure 7a). Br appears most concentrated in such clusters at least as far as $10-13 \mathrm{~cm}$ down the sediment column

\footnotetext{
${ }^{1}$ Auxiliary materials are available in the HTML. doi:10.1029 2010GB003794.
}

(Figure $7 \mathrm{~b}) . \mathrm{Br} \mu$-speciation in these aggregates is predominantly organic (Figure 7c).

[29] By contrast, at 23-25 cm below the sediment-water interface, $\mathrm{Br}$ appears in a more uniform and diffuse distribution, concentrated between mineral grains, in areas of low Fe concentration (Figures 8a and 8b). The speciation of $\mathrm{Br}$ in these interstitial spaces is chiefly inorganic (Figure 8c, spectra b-d). Reducing conditions at deeper depths in the sediment column could encourage reductive debromination of $\mathrm{Br}_{\text {org }}$ moieties by microorganisms, with consequent release of $\mathrm{Br}_{\text {inorg }}$ ion into pore waters [Ahn et al., 2003; Biester et al., 2006; Müller et al., 1996]. Studies of element 

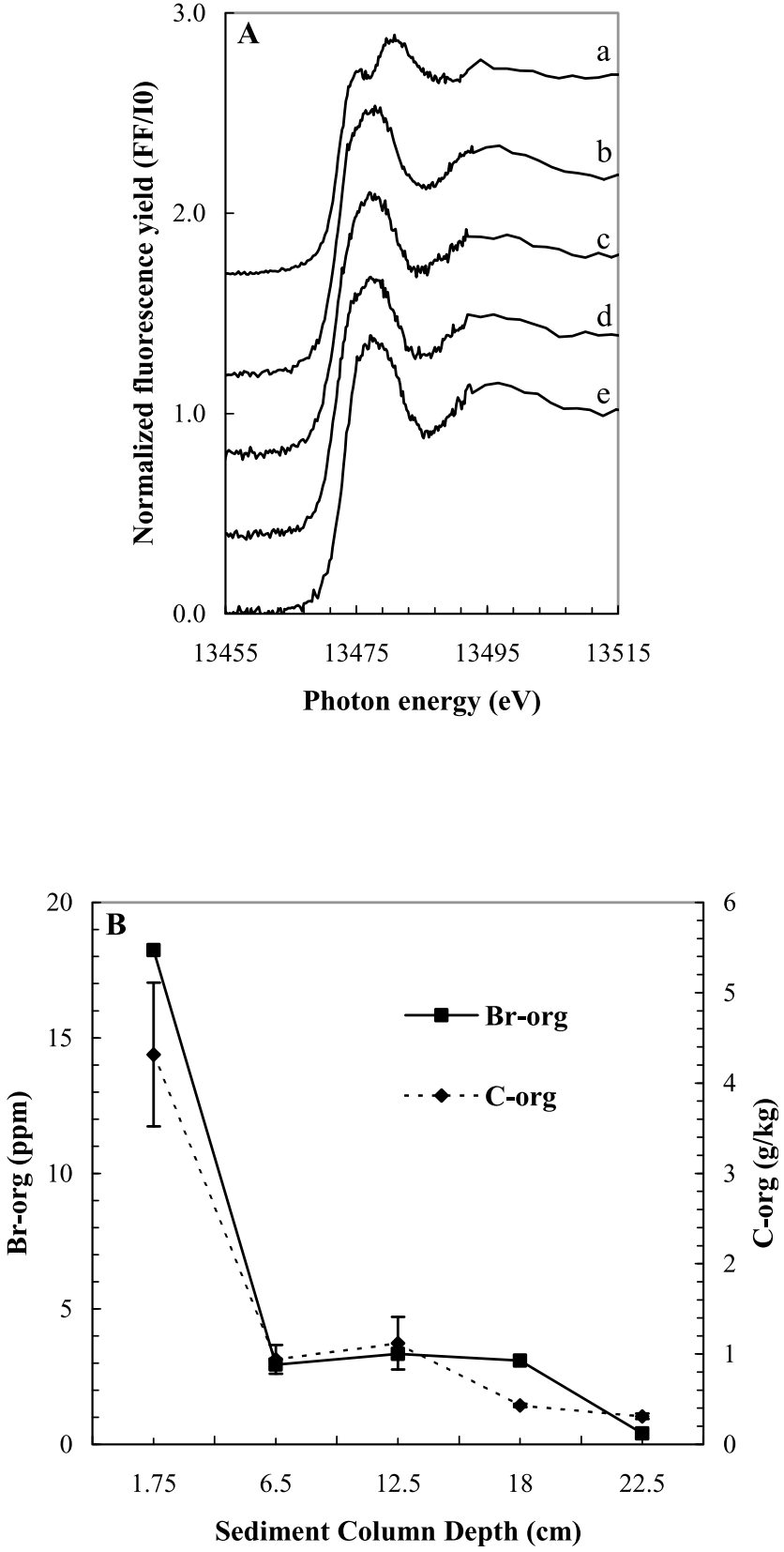

Figure 5. Data from homogenized Cape Cod (MA) estuarine sediment sections. (a) Variation in $\mathrm{Br}$ speciation with sediment column depth. Normalized Br $1 s$ bulk XANES spectra: spectrum a, 0-3.5 cm; spectrum b, 4-9 cm; spectrum c, 9-16 cm; spectrum d, 16-20 cm; spectrum e, 20$25 \mathrm{~cm}$. (b) Relationships between depth, $\mathrm{Br}_{\text {org }}$, and $\mathrm{C}_{\text {org }}$ concentrations.

cycling in marine sediments have interpreted increasing $\mathrm{Br}_{\text {inorg }}$ concentrations in sediment pore waters with depth as evidence that the anion is regenerated as a result of the decomposition of NOM during diagenesis [Mahn and Gieskes, 2001; Martin et al., 1993]. Concentrated $\mathrm{Br}_{\text {org }}$ occurs at $23-25 \mathrm{~cm}$ at sparsely distributed, localized hot spots, which coincide with areas of elevated Fe concentration (Figure 8c, spectrum a). These $\mathrm{Br}_{\text {org }}$ hot spots may represent remnants of the brominated NOM aggregates observed at shallower depths (Figure 7).

[30] In the Cape Cod sediments, associations between $\mathrm{Br}$ and most metal cations are pronounced at the sedimentwater interface and decrease significantly with depth. The values of Pearson $r$ correlation coefficients for the relationship between $\mathrm{Br}$ and other elements decrease by as much as $75 \%$ down the $25 \mathrm{~cm}$ column (see auxiliary material). The strong correlations between $\mathrm{Br}$ and metal cations at shallower depths likely reflect sorption reactions between the metals (or their oxides) and $\mathrm{C}_{\text {org }}$, which comprises $\mathrm{Br}_{\text {org }}$. In the deeper sediments, in which correlations between $\mathrm{Br}$ and metal cations are not as pronounced, $\mathrm{Br}$ is present mainly as $\mathrm{Br}_{\text {inorg }}$ in interstitial spaces rather than being present as $\mathrm{Br}_{\text {org }}$ bound to NOM. These results suggest that $\mathrm{Br}_{\text {org }}$ is correlated with metals in the sediments, while $\mathrm{Br}_{\text {inorg }}$, with its low binding affinity, is not.

[31] Taken together, the phenomena described in this section and the trends in $\mathrm{Br}$ speciation and concentration outlined in section 3.2 hint at bromination and debromination mechanisms related to the cycling of NOM.

\subsection{Sources of Sediment $\mathbf{B r}_{\text {org }}$}

[32] The previous sections demonstrate that marine and estuarine sediments potentially act as a locus for the transformation of $\mathrm{Br}$ between inorganic and organic forms. This phenomenon of $\mathrm{Br}$ cycling in the sediments is supported by the dramatic decrease of $\mathrm{Br}_{\text {org }}$ with depth in most of the samples investigated here (Table 1) and also strikingly depicted in the $\mu$-XRF images of $\mathrm{Br}$ distribution at various depths in undisturbed Cape Cod sediments (Figures 7 and 8).

[33] Before we can adequately describe the marine $\mathrm{Br}$ cycle, the different biotic and abiotic sources of $\mathrm{Br}_{\text {org }}$ in the sediments must be illuminated. A major mechanism of $\mathrm{C}-\mathrm{Br}$ bond production in marine systems is apparent in the bromoperoxidative capabilities common to diverse aquatic organisms [Butler and Carter-Franklin, 2004]. The estuarine sediments from Cape Cod, for example, play host to the bromoaromatic-producing hemichordate worm Saccoglossus kowaleskii [King, 1986]. Benthic organisms such as this have been regarded as indicators of low molecular weight $\mathrm{Br}_{\text {org }}$ in sediments [Fielman et al., 2001]. $\mathrm{Br}_{\text {org }}$ may also form abiotically in sediments during early diagenetic processes as insoluble $\mathrm{Fe}(\mathrm{III})-$ oxides are reduced [Keppler et al., 2000; Schöler and Keppler, 2003].

[34] Much of sediment NOM, however, originates in surface waters, as detrital matter from organisms in the euphotic zone that ultimately settles on the sediment surface. Sinking particles represent the major means of transport of NOM from surface waters to the seafloor [Boyd and Trull, 2007]. In search of $\mathrm{Br}_{\text {org }}$ in sinking particulate matter, we probed $\mathrm{Br}$ speciation and distribution in solid phase material from sediment traps deployed at 258 and $1061 \mathrm{~m}$ down the water column in the Okhotsk Sea [Honda et al., 1997] and at $200 \mathrm{~m}$ in the Ligurian Sea [Goutx et al., 2007].

[35] The Okhotsk Sea is characterized by a rich supply of nutrients and high biological productivity. The $\mathrm{Br}$ in Okhotsk sediment trap material was revealed to be exclu- 

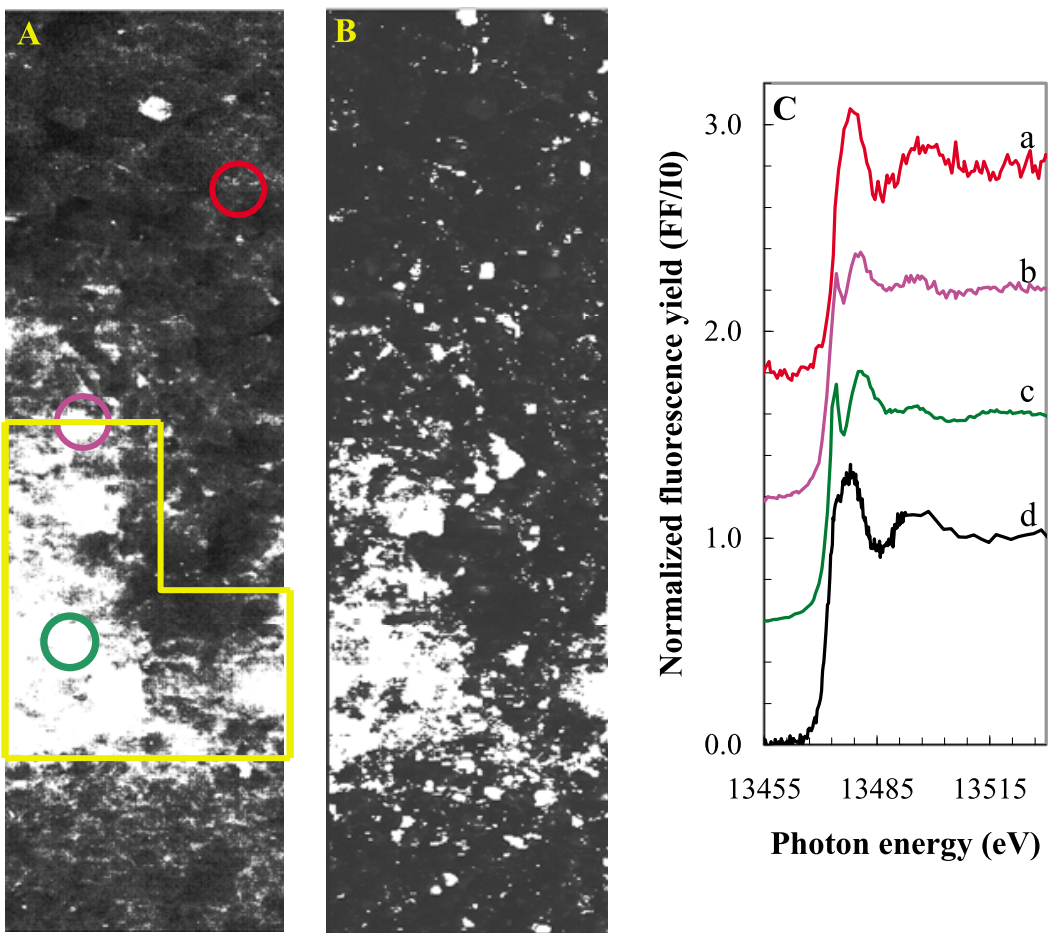

Photon energy (eV)

Figure 6. Undisturbed sediment core section from coastal New Jersey bay waters, $7.2-8.5 \mathrm{~cm}$ below sediment-water interface. The sediment core contained a distinct "lens" of dark-colored NOM $\sim 8 \mathrm{~cm}$ below the sediment-water interface. The core was sectioned for X-ray analysis with minimal disturbance of the sediment grains, and the position of the organic lens was recorded by microscopic observation (yellow outline) once the sample was mounted in the sample chamber, prior to fluorescence map acquisition. (a) Micro-X-ray fluorescence ( $\mu$-XRF) image map at $\mathrm{Br} \mathrm{K} \alpha$ emission energy. Lighter shade corresponds to greater intensity. Map dimensions: $1.3 \times 0.45 \mathrm{~cm}^{2}$. (b) A $\mu$-XRF map for Fe $\mathrm{K} \alpha / \mathrm{Mn} \mathrm{K} \beta$ (these emission energies could not be resolved). (c) Normalized $\mathrm{Br} 1 s \mu$-XANES spectra, where the color of spectral lines corresponds to that of the circled areas in Figure 6a. Least squares fitting with model compounds reveals the speciation of spectrum a to be $100 \% \mathrm{Br}_{\text {inorg }}$ and spectra $\mathrm{b}$ and $\mathrm{c}$ are both

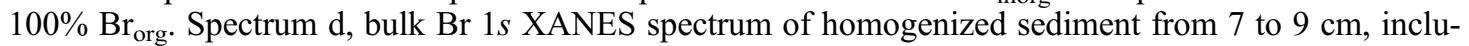
sive of organic lens; $65 \% \mathrm{Br}_{\text {inorg }}, 35 \% \mathrm{Br}_{\text {org }}$. 

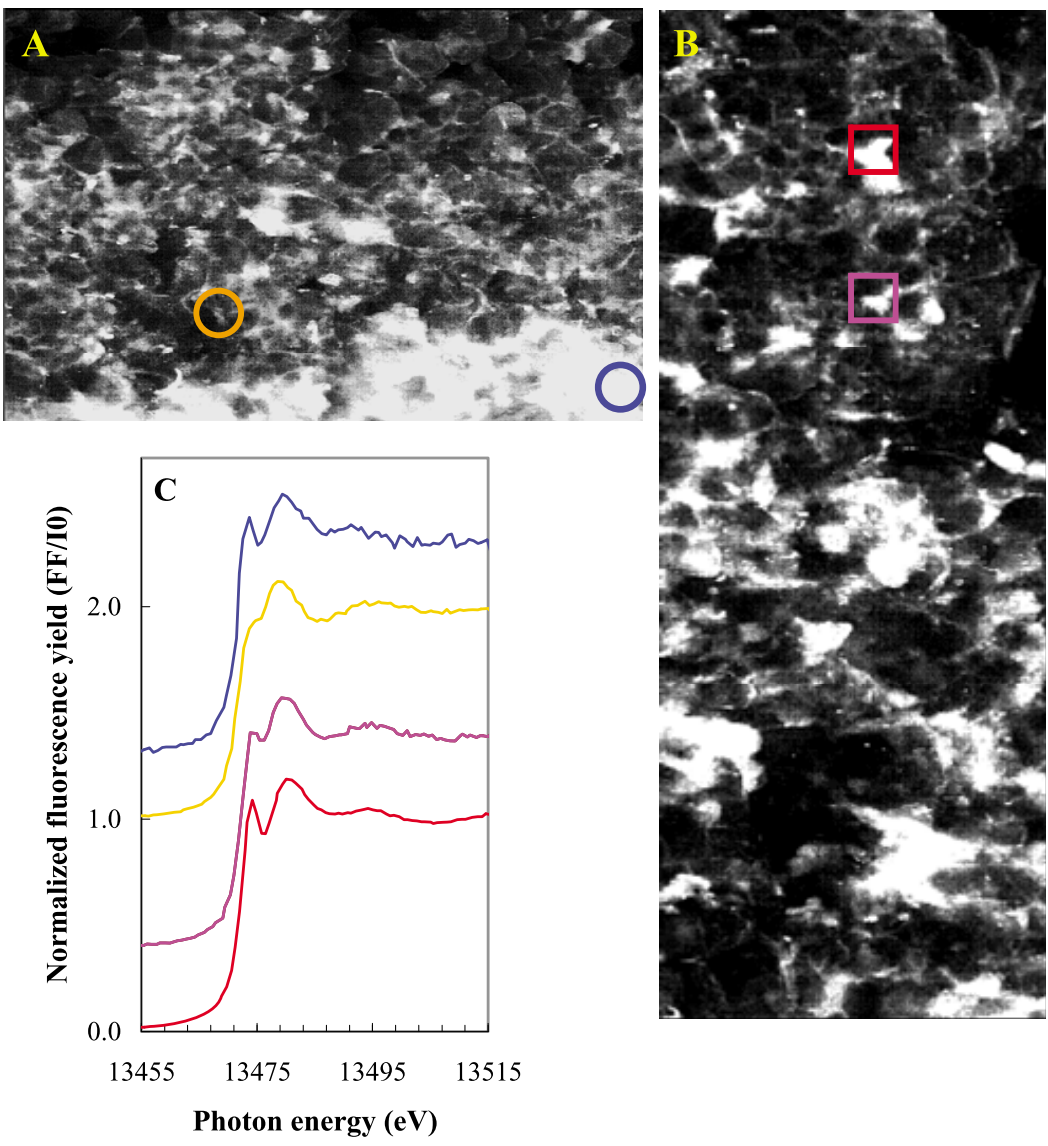

Figure 7. $\mathrm{Br}$ distribution and $\mu$-speciation in upper portions of Cape Cod (MA) estuarine sediment (undisturbed core sections). $\mathrm{Br} \mathrm{K} \alpha \mu$-XRF maps: (a) $0-1 \mathrm{~cm}\left(10 \times 7 \mathrm{~mm}^{2}\right)$ and (b) $10-13 \mathrm{~cm}(5 \times$ $13 \mathrm{~mm}^{2}$ ). Lighter shade corresponds to greater fluorescence intensity, i.e., greater Br concentration. (c) Normalized Br $1 s \mu$-XANES spectra. Colors of open shapes in Figures $7 \mathrm{a}$ and $7 \mathrm{~b}$ match colors of associated $\mu$-XANES spectra in Figure 7c. 

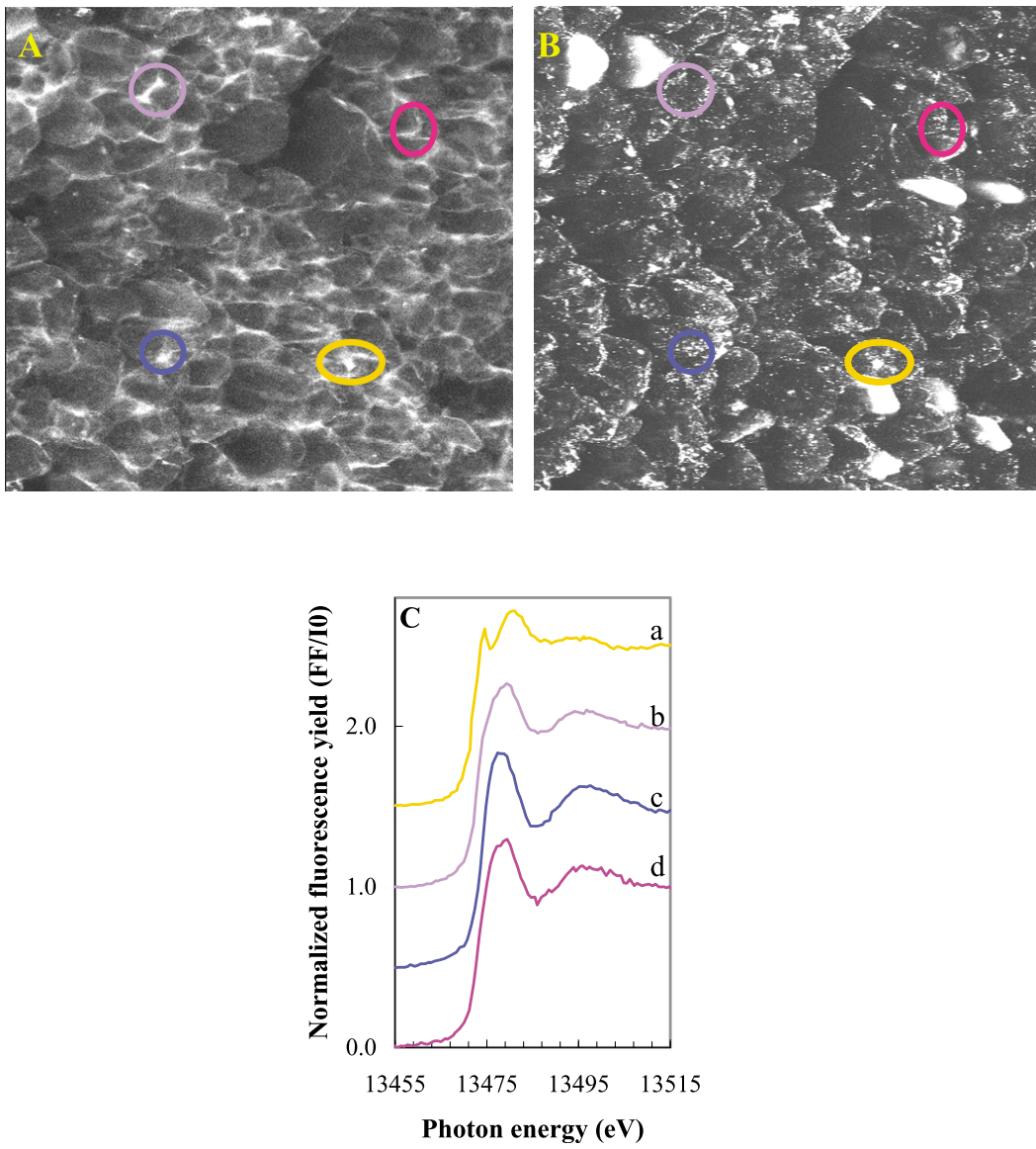

Figure 8. $\mathrm{Br}$ distribution and $\mu$-speciation in lower depths $(23-25 \mathrm{~cm})$ of Cape Cod (MA) estuarine sediment (undisturbed core section). Shown are $\mu$-XRF maps $\left(8 \times 8 \mathrm{~mm}^{2}\right)$ : (a) $\mathrm{Br} \mathrm{K} \alpha$ and (b) Fe $\mathrm{K} \alpha / \mathrm{Mn} \mathrm{K} \beta$. Lighter shade corresponds to greater fluorescence intensity, i.e., greater elemental concentration. (c) Normalized $\mathrm{Br} 1 s \mu$-XANES spectra. Colors of open circles in Figures $8 \mathrm{a}$ and $8 \mathrm{~b}$ match colors of associated $\mu$-XANES spectra in Figure 8c. 


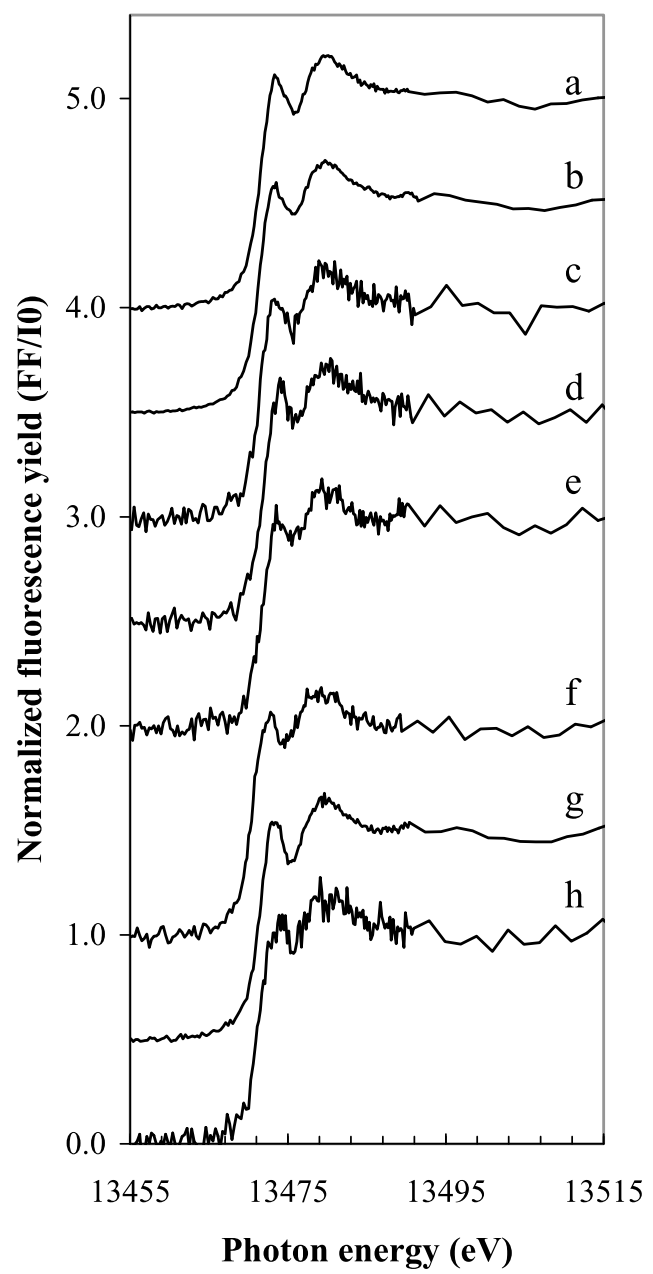

Figure 9. Normalized $\mathrm{Br} 1 s$ bulk XANES spectra of particulate sediment trap material from the Sea of Okhotsk. Sediment traps deployed at $258 \mathrm{~m}$ (spectra a-e) and $1061 \mathrm{~m}$ (spectra $\mathrm{f}-\mathrm{h}$ ) down the water column. Dates of collection: spectrum a, August 1990; spectrum b, October 1990; spectrum c, December 1990 to February 1991; spectrum d, April 1991; spectrum e, June 1991; spectrum f, August 1990; spectrum g, October 1990; spectrum h, December 1990 to February 1991.

sively organic, at both depths and through all seasons (Figure 9). In $\mathrm{Br} \mathrm{K} \alpha \mu$-XRF maps of Okhotsk sediment trap material, $\mathrm{Br}$ distribution is heterogeneous, with prominent areas of high $\mathrm{Br}$ concentration (Figure 10a). The $\mathrm{Ca}$ distribution is similarly heterogeneous, with calcareous shells of coccolithophores clearly evident in $\mathrm{Ca} \mathrm{K} \alpha$ maps (Figure 10b). Comparison of the $\mathrm{Ca} \mathrm{K} \alpha$ and $\mathrm{Br} \mathrm{K} \alpha$ distributions suggests that the areas of highest $\mathrm{Br}$ concentration are not correlated with coccolithophore shells. By contrast, Fe and Mn (Figures 10c-10e) coincide spatially with Br.

[36] In sediment trap material from the Ligurian $\mathrm{Sea}, \mathrm{Br}$ is again correlated with $\mathrm{Fe}$ and $\mathrm{Mn}$ more than $\mathrm{Ca}$ (see auxiliary material). Once more, $\mathrm{Ca}$ appears most prominent in cal- careous fragments, and $\mathrm{Br}$ does not appear at high concentrations in these areas. $\mathrm{Br} 1 s \mu$-XANES spectra reveal that the areas of highest $\mathrm{Br}$ concentration in the sediment trap material correspond to $\mathrm{Br}_{\text {org }}$, while areas of low $\mathrm{Br}$ concentration and high $\mathrm{Ca}$ concentration correspond to $\mathrm{Br}_{\text {inorg }}$ (see auxiliary material). These results suggest that $\mathrm{Br}_{\text {org }}$ is either associated with the lithogenic fraction of the sinking particulates or with a fraction of NOM unrelated to biogenic $\mathrm{CaCO}_{3}$, possibly a diatomaceous fraction. $\mathrm{Br}$ has been found in high concentrations in the frustules of many diatom species and has been used as a proxy of paleoproductivity [Kerfoot et al., 1999; Phedorin et al., 2000]. The $\mu$-XRF beamline does not allow for detection of low-Z elements like Si, so we were unable to measure $\mathrm{Si}-\mathrm{Br}$ correlations in our samples. If diatoms are significant sources of sedimentary $\mathrm{Br}_{\mathrm{org}}$, it could partly explain the observation of the highest $\mathrm{Br}_{\text {org }}$ concentrations in the opal-rich Southern Ocean Antarctic sediments (Table 1).

[37] The observed correlations between $\mathrm{Br}_{\text {org }}$ and metals such as $\mathrm{Fe}$ and $\mathrm{Mn}$ in sediment trap material could arise due to sorption interactions between these metal cations and sinking NOM. This association may also relate to the causality of $\mathrm{Br}_{\text {org }}$ formation, since abiotic reactions between NOM, halides, and redox-active metals have been shown to be environmentally feasible modes of $\mathrm{B}_{\text {org }}$ production [Keppler et al., 2000]. In the euphotic zone, $\mathrm{Br}_{\text {org }}$ compounds may form abiotically through radical photochemical reactions between Fe species, NOM, and $\mathrm{Br}_{\text {inorg }}$ ions [Pelizzetti and Calza, 2002].

[38] The high $\mathrm{Br}_{\text {org }}$ concentrations found in sinking particulate material suggest that a portion of the stable $\mathrm{Br}_{\text {org }}$ observed in marine sediments originates as $\mathrm{Br}_{\text {org }}$ compounds produced in surface waters by biota, such as macroalgae and phytoplankton, or through abiotic processes, such as photochemical reactions. The simple molecules arising from the decomposition of biological and other organic material polymerize to form macromolecular NOM that ultimately undergoes sedimentation, mineralization, or degradation to dissolved species. Thus, it seems feasible that detrital matter from $\mathrm{Br}_{\mathrm{org}}$-producing organisms and abiotic $\mathrm{Br}$ transformations contain $\mathrm{C}-\mathrm{Br}$ bonds that persist through the formation of polyfunctional geomacromolecules and sedimentation. This would account for the ubiquity of $\mathrm{Br}_{\text {org }}$ in estuarine and marine sediments and point to the sediments as sinks of naturally produced $\mathrm{Br}_{\mathrm{org}}$, which is ultimately debrominated through the degradation of NOM. Decreasing $\mathrm{Br}_{\text {org }}: \mathrm{C}_{\text {org }}$ ratios with sediment depth at two of our locations imply that $\mathrm{Br}_{\text {org }}$ is preferentially degraded during diagenesis, a rich topic for further investigation.

\section{Summary and Implications for the Geochemical Br Cycle}

[39] These results show that stable $\mathrm{Br}_{\text {org }}$ constitutes the dominant form of $\mathrm{Br}$ in the organic fraction of estuarine and marine sediments from various geological environments. By extension, the documented associations between $\mathrm{Br}$ and $\mathrm{C}_{\text {org }}$ in marine sediments [Mayer et al., 1981; Price et al., 1970; Pruysers et al., 1991; Tenhaven et al., 1988; Ziegler et al., 

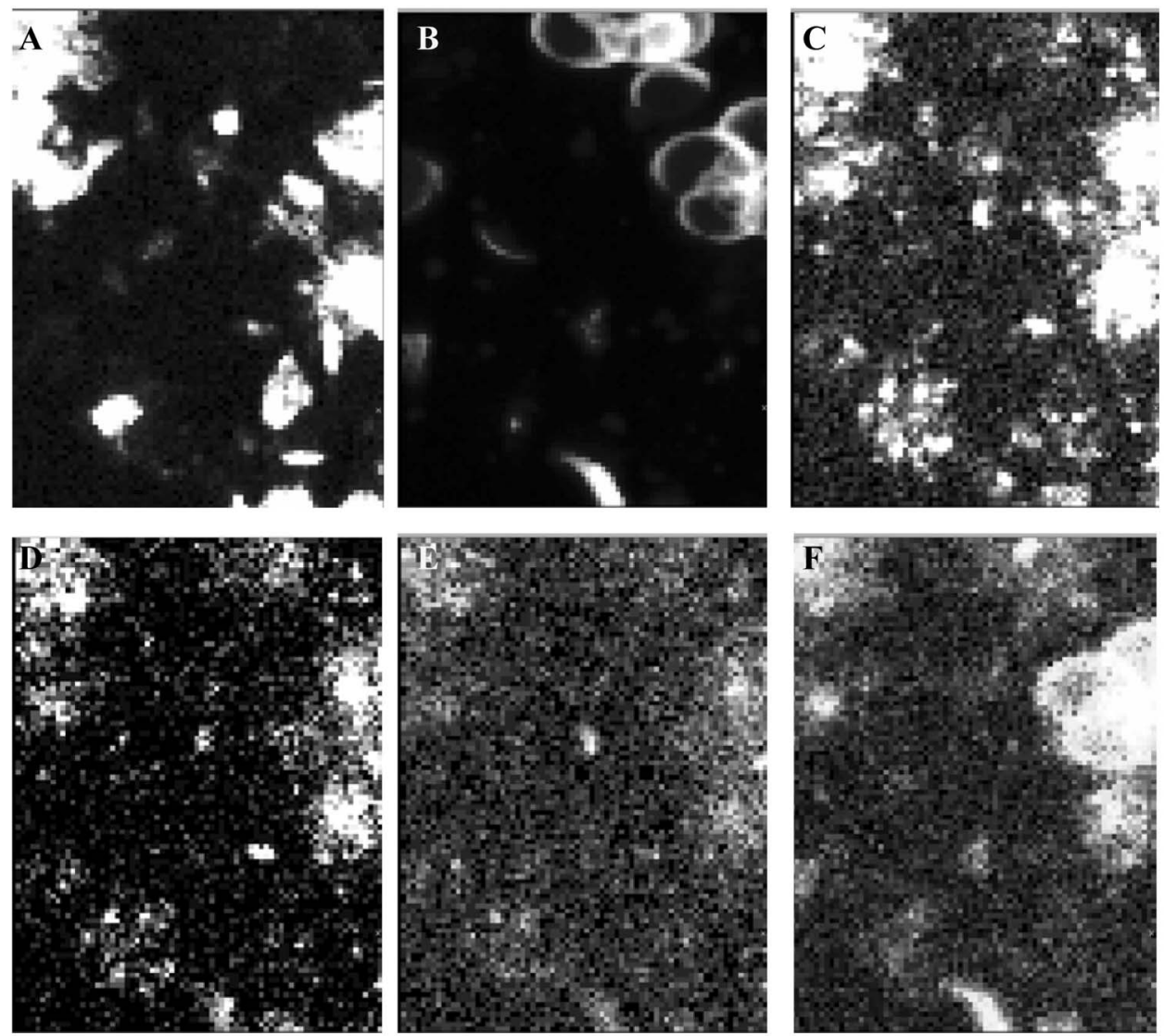

Figure 10. Elemental distributions in particulate sediment trap material from the Sea of Okhotsk. Shown are $\mu$-XRF maps $\left(0.5 \times 0.3 \mathrm{~mm}^{2}\right)$ : (a) $\mathrm{Br} \mathrm{K} \alpha$, (b) $\mathrm{Ca} \mathrm{K} \alpha$, (c) $\mathrm{Fe} \mathrm{K} \alpha / \mathrm{Mn} \mathrm{K} \beta$, (d) $\mathrm{Co} \mathrm{K} \alpha / \mathrm{Fe}$ $\mathrm{K} \beta$, (e) $\mathrm{Mn} \mathrm{K} \alpha$, and (f) $\mathrm{Zn} \mathrm{K} \alpha$. Lighter shade corresponds to greater fluorescence intensity, i.e., greater elemental concentration.

2008] are probably attributable to covalent $\mathrm{C}-\mathrm{Br}$ bonds. It appears therefore that $\mathrm{Br}$ incorporated into geomacromolecules (e.g., humics) as $\mathrm{Br}_{\text {org }}$ accounts for a major reservoir of this halogen in the pedosphere, in line with recent observations of terrestrial peat bogs [Biester et al., 2006, 2004]. The omnipresence of $\mathrm{Br}_{\text {org }}$ in the environmental samples examined and the changing $\mathrm{Br}$ speciation with sediment column depth suggest that the $\mathrm{Br}_{\text {org }}$ functionality not only affects the chemistry of specific microenvironments but participates in a complex, universal biogeochemical cycle involving formation of the $\mathrm{C}-\mathrm{Br}$ bond, humification, and ultimate regeneration of $\mathrm{Br}_{\text {inorg }}$ through the degradation of NOM. The magnitude of Br cycling must now be evaluated in the context of the global marine Br budget to reassess the classification of $\mathrm{Br}$ as a conservative element in seawater [Morris and Riley, 1966]. The relative contributions of biotic and abiotic bromination pathways in the environment require further exploration as well. Ultimately, discovering how ecosystems accommodate $\mathrm{Br}_{\text {org }}$ produced naturally on such a wide scale may influence the assessment of environments polluted by anthropogenic chemicals with analogous chemical properties.
[40] Acknowledgments. The authors are indebted to M. Hay, J. Majzlan, D. Sigman, B. Ward, S. Manganini, R. Robinson, D. Graham, C. Lee, C. Nelson, W. Rao, and the SSRL staff scientists. This investigation was funded by the U.S. Department of Energy, Office of Basic Energy Sciences (DOE-BES) Chemical and Geosciences Programs, the National Science Foundation (NSF) Chemical Sciences Program, and an NSF Graduate Research Fellowship (ACL). Use of the ALS was supported by the DOE-BES Materials Sciences Division under contract DE-AC0376SF00098. Use of the SSRL, a national user facility operated by Stanford University, was supported by the DOE-BES. Use of the NSLS was supported by the DOE-BES under contract DE-AC02-98CH10886. Portions of this work were performed at beamline X26A at the NSLS. Beamline $\mathrm{X} 26 \mathrm{~A}$ is supported by the DOE-Geosciences (DE-FG02-92ER 14244 to the University of Chicago-CARS) and DOE Office of Biological and Environmental Research, Environmental Remediation Sciences Division (DE-FC09-96-SR18546 to the University of Georgia). The authors are grateful for the constructive suggestions provided by two anonymous reviewers.

\section{References}

Ahn, Y.-B., S.-K. Rhee, D. E. Fennell, L. J. Kerkhof, U. Hentschel, and M. M. Häggblom (2003), Reductive dehalogenation of brominated phenolic compounds by microorganisms associated with the marine sponge Aplysina aerophoba, Appl. Environ. Microbiol., 69(7), 4159-4166, doi:10.1128/AEM.69.7.4159-4166.2003.

Berger, D. L. (1984), Screening procedure for total organic halogen, Anal. Chem., 56(12), 2271-2272, doi:10.1021/ac00276a071. 
Bergknut, M., P. Persson, and U. Skyllberg (2008), Molecular characterization of brominated persistent pollutants using extended X-ray absorption fine structure (EXAFS) spectroscopy, Anal. Bioanal. Chem., 390(3), 921-928, doi:10.1007/s00216-007-1721-1.

Bertsch, P. M., and D. B. Hunter (2001), Applications of synchrotronbased X-ray microprobes, Chem. Rev., 101(6), 1809-1842, doi:10.1021/ cr990070s.

Biester, H., F. Keppler, A. Putschew, A. Martinez-Cortizas, and M. Petri (2004), Halogen retention, organohalogens, and the role of organic matter decomposition on halogen enrichment in two Chilean peat bogs, Environ. Sci. Technol., 38(7), 1984-1991, doi:10.1021/es0348492.

Biester, H., D. Selimovic, S. Hemmerich, and M. Petri (2006), Halogens in pore water of peat bogs - The role of peat decomposition and dissolved organic matter, Biogeosciences, 3(1), 53-64, doi:10.5194/bg-3-53-2006.

Boyd, P. W., and T. W. Trull (2007), Understanding the export of biogenic particles in oceanic waters: Is there consensus?, Prog. Oceanogr., 72(4), 276-312, doi:10.1016/j.pocean.2006.10.007.

Butler, A., and J. N. Carter-Franklin (2004), The role of vanadium bromoperoxidase in the biosynthesis of halogenated marine natural products, Nat. Prod. Rep., 21(1), 180-188, doi:10.1039/B302337K.

Carpenter, L. J., and P. S. Liss (2000), On temperate sources of bromoform and other reactive organic bromine gases, J. Geophys. Res., 105(D16), 20,539-20,547, doi:10.1029/2000JD900242.

Cook, M. S., L. D. Keigwin, and C. A. Sancetta (2005), The deglacial history of surface and intermediate water of the Bering Sea, Deep Sea Res. Part II, 52(16-18), 2163-2173, doi:10.1016/j.dsr2.2005.07.004.

Darnerud, P. O. (2003), Toxic effects of brominated flame retardants in man and in wildlife, Environ. Int., 29(6), 841-853, doi:10.1016/S01604120(03)00107-7.

Dembitsky, V. M. (2002), Bromo- and iodo-containing alkaloids from marine microorganisms and sponges, Russ. J. Bioorg. Chem., 28(3), 170-182, doi:10.1023/A:1015748018820.

Fielman, K. T., S. A. Woodin, and D. E. Lincoln (2001), Polychaete indicator species as a source of natural halogenated organic compounds in marine sediments, Environ. Toxicol. Chem., 20(4), 738-747, doi:10.1002/etc.5620200407.

Goutx, M., S. G. Wakeham, C. Lee, M. Duflos, C. Guigue, Z. Liu, B. Moriceau, R. Sempere, M. Tedetti, and J. Xue (2007), Composition and degradation of marine particles with different settling velocities in the northwest Mediterranean Sea, Limnol. Oceanogr., 52(4), 1645-1664.

Gribble, G. W. (2000), The natural production of organobromine compounds, Environ. Sci. Pollut. Res., 7(1), 37-49, doi:10.1065/ espr199910.002.

Gribble, G. W. (2003), The diversity of naturally produced organohalogens, Chemosphere, 52(2), 289-297, doi:10.1016/S0045-6535(03)00207-8.

Harper, F. (1984), History and implementation of total organic halogen methodology as an indicator of ground water quality, Ground Water Monit. Rem., 4(1), 46-48, doi:10.1111/j.1745-6592.1984.tb01219.x.

Honda, M. C., M. Kusakabe, S. Nakabayashi, S. J. Manganini, and S. Honjo (1997), Change in $\mathrm{pCO}_{2}$ through biological activity in the marginal seas of the western North Pacific, J. Oceanogr., 53, 645-662.

Johansson, C., I. Pavasars, H. Borén, and A. Grimvall (1994), A degradation procedure for determination of halogenated structural elements in organic matter from marine sediments, Environ. Int., 20(1), 103-111, doi:10.1016/0160-4120(94)90073-6.

Keppler, F., R. Eiden, V. Niedan, J. Pracht, and H. F. Schöler (2000), Halocarbons produced by natural oxidation processes during degradation of organic matter, Nature, 403, 298-301, doi:10.1038/35002055.

Kerfoot, W. C., J. A. Robbins, and L. J. Weider (1999), A new approach to historical reconstruction: Combining descriptive and experimental paleolimnology, Limnol. Oceanogr., 44(5), 1232-1247, doi:10.4319/1o. 1999.44.5.1232.

King, G. M. (1986), Inhibition of microbial activity in marine sediments by a bromophenol from a hemichordate, Nature, 323, 257-259, doi:10.1038/ $323257 \mathrm{a} 0$.

La Barre, S., P. Potin, C. Leblanc, and L. Delage (2010), The halogenated metabolism of brown algae (Phaeophyta), its biological importance and its environmental significance, Mar. Drugs, 8(4), 988-1010, doi: $10.3390 / \mathrm{md} 8040988$.

Lane, A. L., et al. (2009), Desorption electrospray ionization mass spectrometry reveals surface-mediated antifungal chemical defense of a tropical seaweed, Proc. Natl. Acad. Sci. U. S. A., 106(18), 7314-7319, doi:10.1073/pnas.0812020106.

Laturnus, F., B. Giese, C. Wiencke, and F. C. Adams (2000), Lowmolecular-weight organoiodine and organobromine compounds released by polar macroalgae-The influence of abiotic factors, Fresenius J. Anal. Chem., 368(2-3), 297-302, doi:10.1007/s002160000491.
Lehmann, M. F., D. M. Sigman, D. C. McCorkle, B. G. Brunelle, S. Hoffmann, M. Kienast, G. Cane, and J. Clement (2005), Origin of the deep Bering Sea nitrate deficit: Constraints from the nitrogen and oxygen isotopic composition of water column nitrate and benthic nitrate fluxes, Global Biogeochem. Cycles, 19, GB4005, doi:10.1029/ 2005GB002508

Leri, A. C., M. B. Hay, A. Lanzirotti, W. Rao, and S. C. B. Myneni (2006), Quantitative determination of absolute organohalogen concentrations in environmental samples by X-ray absorption spectroscopy, Anal. Chem. 78(16), 5711-5718, doi:10.1021/ac060476m.

Mahn, C. L., and J. M. Gieskes (2001), Halide systematics in comparison with nutrient distributions in sites $1033 \mathrm{~B}$ and 1034B, Saanich Inlet: ODP Leg 169S, Mar. Geol., 174(1-4), 323-339, doi:10.1016/S0025-3227(00) 00158-4.

Marcus, M. A., A. A. MacDowell, R. Celestre, A. Manceau, T. Miller, H. A. Padmore, and R. E. Sublett (2004), Beamline 10.3.2 at ALS: A hard $\mathrm{X}$-ray microprobe for environmental and materials sciences, J. Synchrotron Radiat., 11, 239-247, doi:10.1107/S0909049504005837.

Martin, J. B., J. M. Gieskes, M. Torres, and M. Kastner (1993), Bromine and iodine in Peru margin sediments and pore fluids: Implications for fluid origins, Geochim. Cosmochim. Acta, 57(18), 4377-4389, doi:10.1016/0016-7037(93)90489-J.

Mayer, L. M., S. A. Macko, W. H. Mook, and S. Murray (1981), The distribution of bromine in coastal sediments and its use as a source indicator for organic matter, Org. Geochem., 3(1-2), 37-42, doi:10.1016/01466380(81)90011-5

Mayer, L. M., L. L. Schick, M. A. Allison, K. C. Ruttenberg, and S. J. Bentley (2007), Marine vs. terrigenous organic matter in Louisiana coastal sediments: The uses of bromine:organic carbon ratios, Mar. Chem., 107(2), 244-254, doi:10.1016/j.marchem.2007.07.007.

Morris, A. W., and J. P. Riley (1966), The bromide/chlorinity and sulphate/ chlorinity ratio in sea water, Deep Sea Res. Oceanogr. Abstr., 13(4), 699-705, doi:10.1016/0011-7471(66)90601-2.

Müller, G., G. Nkusi, and H. F. Schöler (1996), Natural organohalogens in sediments, J. Prakt. Chem. Chem.-Ztg., 338(1), 23-29, doi:10.1002/ prac. 19963380104

Norstrom, R. J., M. Simon, J. Moisey, B. Wakeford, and D. V. C. Weseloh (2002), Geographical distribution (2000) and temporal trends (19812000) of brominated diphenyl ethers in Great Lakes herring gull eggs, Environ. Sci. Technol., 36(22), 4783-4789, doi:10.1021/es025831e.

Pelizzetti, E., and P. Calza (2002), Photochemical processes in the euphotic zone of sea water: Progress and problems, in Chemistry of Marine Water and Sediments, edited by A. Gianguzza et al., pp. 83-103, Springer, Berlin.

Phedorin, M. A., E. L. Goldberg, M. A. Grachev, O. L. Levina, O. M. Khlystov, and I. P. Dolbnya (2000), The comparison of biogenic silica, $\mathrm{Br}$, and $\mathrm{Nd}$ distributions in the sediments of Lake Baikal as proxies of changing paleoclimates of the last $480 \mathrm{kyr}$, Nucl. Instrum. Methods Phys. Res., Sect. A, 448(1-2), 400-406, doi:10.1016/S0168-9002(99)00726-3.

Price, N. B., S. E. Calvert, and P. G. W. Jones (1970), Distribution of iodine and bromine in sediments of the southwestern Barents Sea, J. Mar. Res., 28(1), 22-34.

Pruysers, P. A., G. J. Delange, and J. J. Middelburg (1991), Geochemistry of eastern Mediterranean sediments-Primary sediment composition and diagenetic alterations, Mar. Geol., 100(1-4), 137-154, doi:10.1016/ 0025-3227(91)90230-2.

Putschew, A., F. Keppler, and M. Jekel (2003), Differentiation of the halogen content of peat samples using ion chromatography after combustion (TX/TOX-IC), Anal. Bioanal. Chem., 375(6), 781-785, doi:10.1007/ s00216-003-1797-1.

Quack, B., E. Atlas, G. Petrick, V. Stroud, S. Schauffler, and D. W. R. Wallace (2004), Oceanic bromoform sources for the tropical atmosphere, Geophys. Res. Lett., 31, L23S05, doi:10.1029/2004GL020597.

Ressler, T. (1998), WinXAS: A program for X-ray absorption spectroscopy data analysis under MS-Windows, J. Synchrotron Radiat., 5, 118-122, doi:10.1107/S0909049597019298.

Robinson, R. S., B. G. Brunelle, and D. M. Sigman (2004), Revisiting nutrient utilization in the glacial Antarctic: Evidence from a new method for diatom-bound $\mathrm{N}$ isotopic analysis, Paleoceanography, 19, PA3001, doi:10.1029/2003PA000996.

Santillo, D., and P. Johnston (2003), Playing with fire: The global threat presented by brominated flame retardants justifies urgent substitution, Environ. Int., 29(6), 725-734, doi:10.1016/S0160-4120(03)00115-6.

Santos, I. R., D. I. T. Fávaro, C. E. G. R. Schaefer, and E. V. Silva-Filho (2007), Sediment geochemistry in coastal maritime Antarctica (Admiralty Bay, King George Island): Evidence from rare earths and other 
elements, Mar. Chem., 107(4), 464-474, doi:10.1016/j.marchem. 2007.09.006.

Schöler, H. F., and F. Keppler (2003), Abiotic formation of organohalogens during early diagenetic processes, Handb. Environ. Chem., 3P, 63-84, doi:10.1007/b10446.

Simmons, R. C., A. J. Gold, and P. M. Groffman (1992), Nitrate dynamics in riparian forests: Groundwater studies, J. Environ. Qual., 21(4), 659-665, doi:10.2134/jeq1992.00472425002100040021x.

Tanner, C. C., and J. P. Sukias (1995), Accumulation of organic solids in gravel-bed constructed wetlands, Water Sci. Technol., 32(3), 229-239, doi:10.1016/0273-1223(95)00624-9.

Tenhaven, H. L., J. W. Deleeuw, P. A. Schenck, and G. T. Klaver (1988), Geochemistry of Mediterranean sediments-Bromine/organic carbon and uranium/organic carbon ratios as indicators for different sources of input and post-depositional oxidation, respectively, Org. Geochem., 13(1-3), 255-261, doi:10.1016/0146-6380(88)90044-7.

Theiler, R., J. C. Cook, L. P. Hager, and J. F. Siuda (1978), Halohydrocarbon synthesis by bromoperoxidase, Science, 202(4372), 1094-1096, doi:10.1126/science. 202.4372.1094.

Weaver, R. W., M. C. Stecher, and K. McInnes (2003), Water flow patterns in subsurface flow constructed wetlands designed for on-site domestic wastewater treatment, Environ. Technol., 24(1), 77-86, doi:10.1080/ 09593330309385538 .
Wever, R., M. G. M. Tromp, B. E. Krenn, A. Marjani, and M. Van Tol (1991), Brominating activity of the seaweed Ascophyllum nodosum: Impact on the biosphere, Environ. Sci. Technol., 25(3), 446-449, doi:10.1021/es00015a010.

Ziegler, M., T. Jilbert, G. J. de Lange, L. J. Lourens, and G.-J. Reichart (2008), Bromine counts from XRF scanning as an estimate of the marine organic carbon content of sediment cores, Geochem. Geophys. Geosyst., 9, Q05009, doi:10.1029/2007GC001932.

J. A. Hakala and S. C. B. Myneni, Department of Geosciences, Princeton University, Princeton, NJ 08544, USA.

A. Lanzirotti, Consortium for Advanced Radiation Sources, University of Chicago, 5640 S. Ellis Ave., Chicago, IL 60637, USA.

A. C. Leri, Department of Natural Sciences and Mathematics, Marymount Manhattan College, 221 E. 71st St., New York, NY 10021, USA. (aleri@ mmm.edu)

M. A. Marcus, Advanced Light Source, Lawrence Berkeley National Laboratory, 1 Cyclotron Rd., Berkeley, CA 94720, USA.

C. M. Reddy, Department of Marine Chemistry and Geochemistry, Woods Hole Oceanographic Institution, Woods Hole, MA 02543, USA 